\title{
Taxonomic Studies on Brochothrix, Erysipelothrix, Listeria and Atypical Lactobacilli
}

\author{
By SARA B. FERESU† AND DOROTHY JONES* \\ Department of Microbiology, University of Leicester, University Road, Leicester LE1 7RH, UK
}

(Received 20 October 1987; revised 21 January 1988)

\begin{abstract}
One hundred and eighty-seven strains of listeriae, atypical lactobacilli, Brochothrix, Erysipelothrix and related Gram-positive bacteria were tested for 140 characters based on morphology, physiology and biochemistry. Computer analyses of the data resulted in the recovery of 20 phenons. Representative strains were examined for cytochrome content, cell wall, fatty acid and isoprenoid quinone composition and the $G+C$ content of the DNA. The results indicate that the species Listeria monocytogenes, $L$. innocua and $L$. ivanovii are phenotypically very similar. $L$. grayi and $L$. murrayi are more distinct from these but are so similar to each other that $L$. murrayi should be regarded as a subspecies of $L$. grayi. Some of the atypical lactobacilli studied are members of the genus Brochothrix; the others probably represent four distinct species in a new genus.
\end{abstract}

\section{INTRODUCTION}

The genera Brochothrix, Erysipelothrix and Listeria all contain Gram-positive, non-sporing, facultatively anaerobic, regular, rod-shaped bacteria, some of which share other common characteristics and in some properties resemble some, as yet, unclassified bacteria referred to as atypical lactobacilli.

Currently the genus Brochothrix is monospecific but there is evidence of heterogeneity amongst strains designated $B$. thermosphacta (see Sneath \& Jones, 1986). There is also evidence of heterogeneity amongst strains of $E$. rhusiopathiae, until recently the only recognized species in the genus Erysipelothrix (see Jones, 1986). While it is now accepted that L. denitrificans is not a member of the genus Listeria, there is disagreement on the status of the species $L$. grayi and $L$. murrayi (see Seeliger \& Jones, 1986). Furthermore, there are few phenotypic characters to distinguish, with certainty, between the other species of the genus Listeria (Rocourt et al., $1983 \mathrm{~b}$; Rocourt \& Catimel, 1985).

All three genera, Brochothrix, Erysipelothrix and Listeria, contain bacteria of economic importance. E. rhusiopathiae and some listeriae are pathogenic for animals and man; $B$. thermosphacta is a meat spoilage organism. It is therefore important that newly isolated Grampositive, non-sporeforming, facultatively anaerobic rod-shaped bacteria be identified with confidence. While many such bacteria can be identified as members of the above genera or of the genus Lactobacillus, many cannot and these have been referred to as atypical or unclassifiable lactobacilli (Thornley \& Sharpe, 1959; Carr \& Davies, 1970; Shaw \& Harding, 1984).

In an attempt to clarify the taxonomy of the genera Brochothrix, Erysipelothrix and Listeria, and to classify some atypical lactobacilli, numerical taxonomic and some chemical studies were done on these and some representatives of other phenotypically similar bacteria.

\section{METHODS}

Strains and growth conditions. Strains and their sources, where known, are listed in Table 1. Type strains were included wherever possible. To monitor the reproducibility of the test system, 14 cultures were duplicated and

$†$ Present address: Department of Biological Sciences, PO Box MP 167, Mount Pleasant, Harare, Zimbabwe. 
Table 1. Designation, source and cluster assignment of strains plus mol $\% G+C$ values of the DNA of some strains

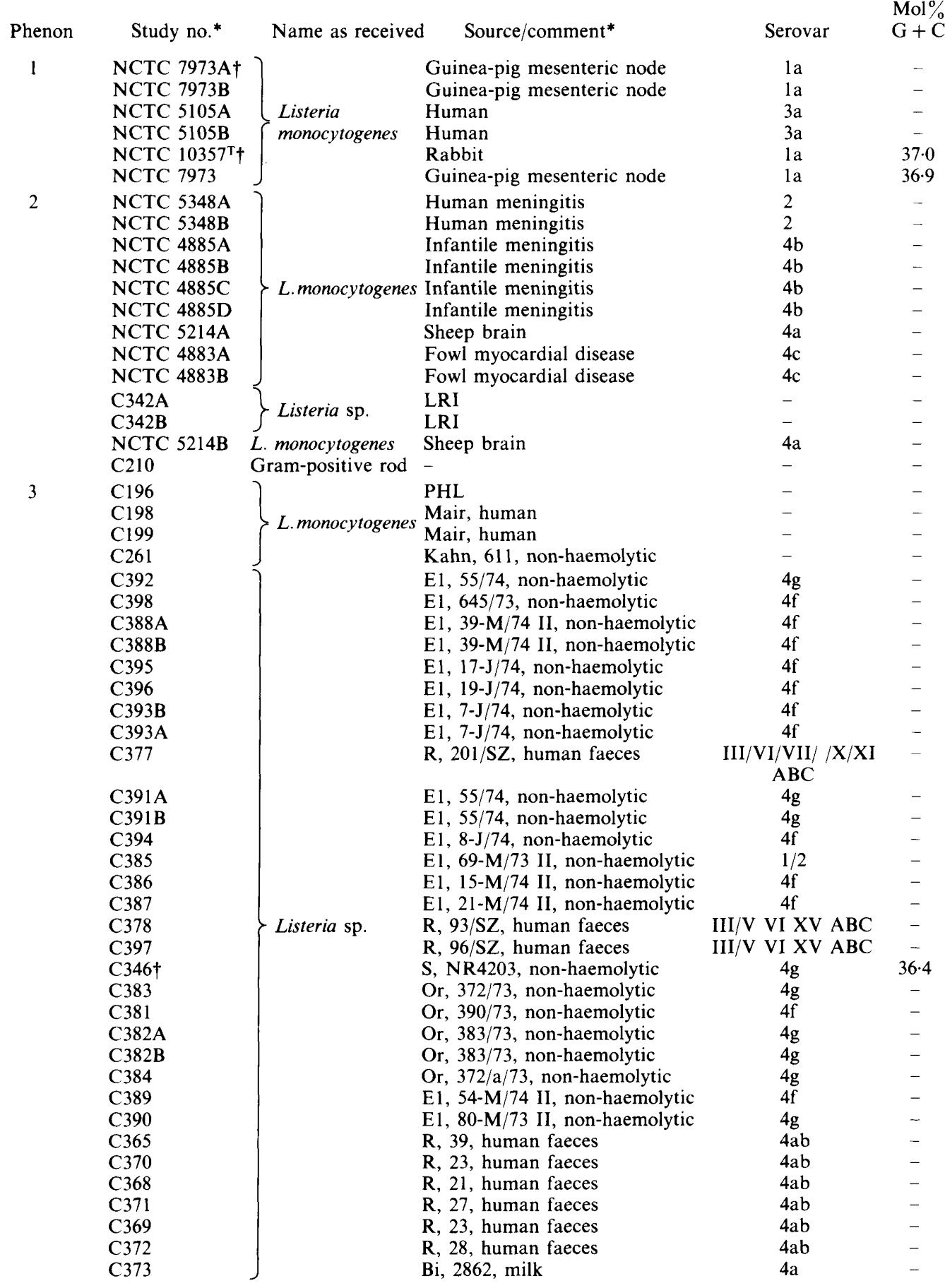


Taxonomy of Gram-positive, non-sporing rods

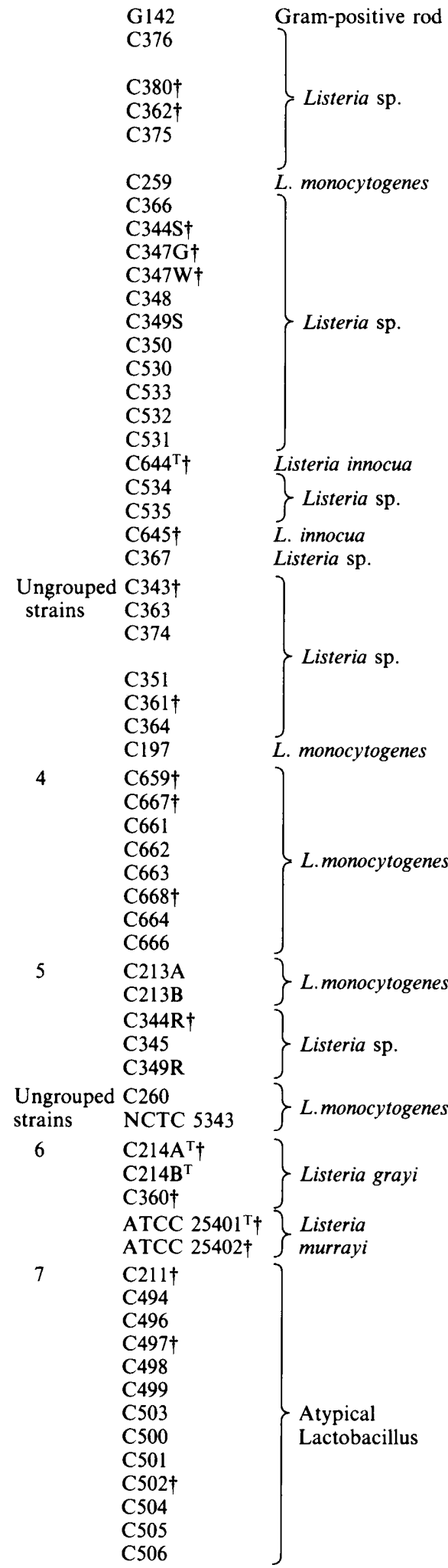

R, 17/SZ, human faeces

$\mathrm{R}, 75 / \mathrm{SZ}$, human faeces

Fo, 46, human faeces

$\mathrm{R}, 21 / \mathrm{SZ}$, human faeces

Kahn, 5607169

Fo, 84, human faeces

S, NR4205, non-haemolytic

S, NR4212, non-haemolytic

S, NR4212, non-haemolytic

S, NR4057, non-haemolytic

S, NR4067, non-haemolytic

S, NR4202, non-haemolytic

Wat, L11, sewage

Wat, L10, sewage

Wat, L4, sewage

Wat, L3, sewage

S, no. 3379

Wat, L5, sewage

Wat, L6, sewage

S, no. 3479

$\mathrm{R}, 10$, human faeces

S, NR4204, non-haemolytic

Fo, 80, human species

R, 19K, human faeces

S, NR4211, non-haemolytic

$R$, 39, human faeces

$R, 81$, human faeces

Mair, 28251, human

P, L242, sheep

P, L102B

$P$, L102A

$P, \mathrm{L133}$, sheep

$\mathrm{P}, \mathrm{L72}$

$P$, L236, sheep

$\mathrm{P}, \mathrm{L} 173$

P, L234, sheep

$\mathrm{S}, \mathrm{L} 88 / 7$, rough strain

$S$, L88/7, rough strain

$S$, NR4205, rough strain

S, NR4206, non-haemolytic

S, NR4067, non-haemolytic

Kahn 611

S, $332 / 64$, chinchilla

III/VI/VII/ / X/XI $\mathrm{ABC}$

III/VI ABC $4 \mathrm{ab}$

III/VI/VII/ /X/XI

$\mathrm{ABC}$

4ab

$4 \mathrm{~g}$

$4 \mathrm{~g}$

$4 \mathrm{~g}$

$4 \mathrm{f}$

$4 \mathrm{~g}$

$4 \mathrm{~g}$

-

$-$

$-$

6a

-

6b $\quad 36 \cdot 3$

$4 \mathrm{ab} \quad 36.8$

$4 \mathrm{~g}$

$4 \mathrm{ab}$

III/VI/VII/ / X/XI

$\mathrm{ABC}$

$4 \mathrm{~g}$

$4 a b$

$4 \mathrm{ab}$

$6 \cdot 8$

5

$36 \cdot 8$

S, 332/64, chinchilla

Seeliger

Corn plant

Corn plant

LTRS MT36, chicken meat

Sharpe, MT34, chicken meat

Sharpe, MT37(L), chicken meat

Sharpe, MT37(S), chicken meat

Sharpe, MT38, chicken meat

Sharpe, MT39(S), chicken meat

Sharpe, MT42(L), chicken meat

Sharpe, MT39(L), chicken meat

Sharpe, MT40, chicken meat

Sharpe, MT41, chicken meat

Sharpe, MT42(S), chicken meat

Sharpe, MT43(L), chicken meat Sharpe, MT43(S), chicken meat 
Table 1 (continued)

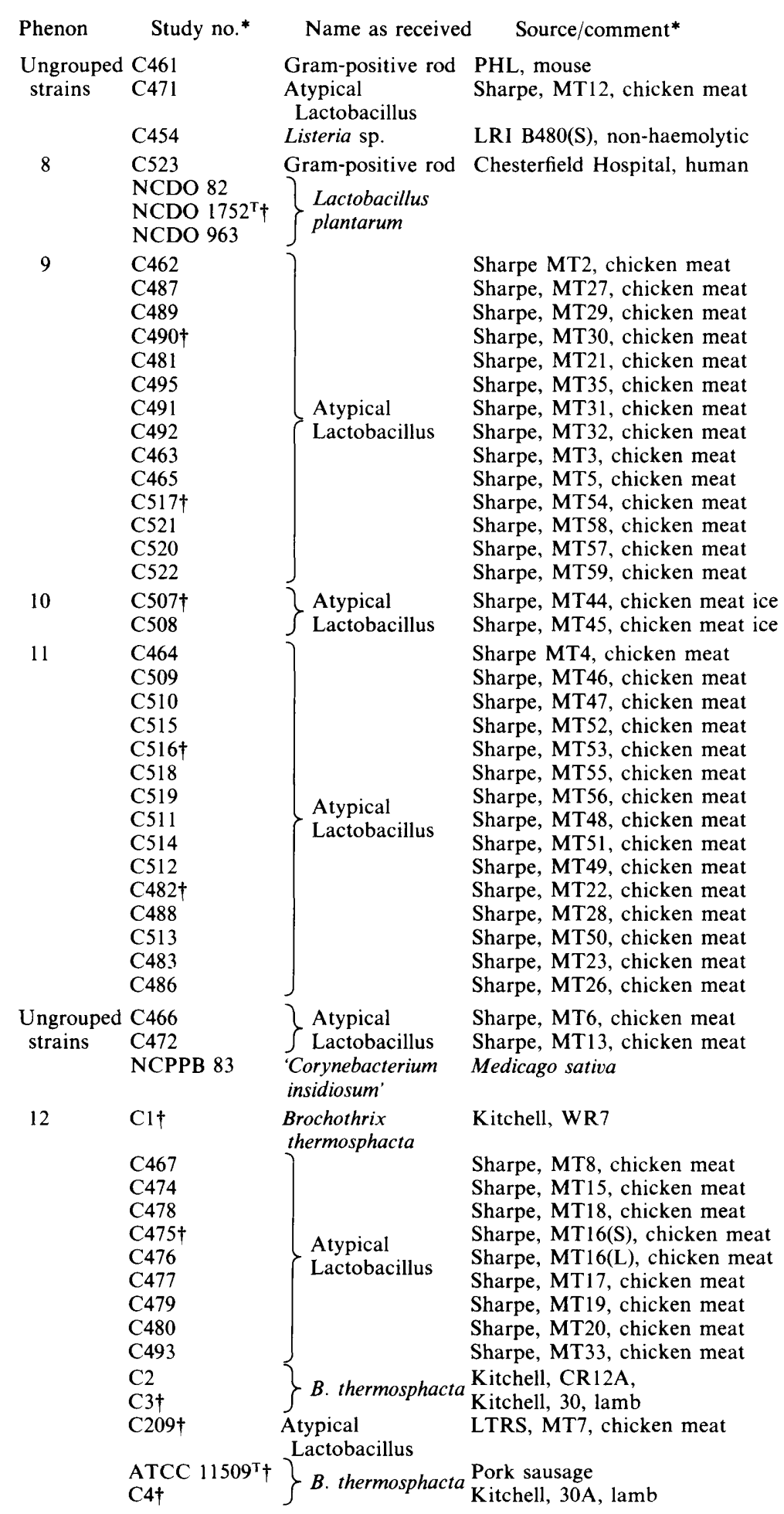

$\begin{array}{ll}\text { Serovar } & \mathrm{Mol} \% \\ \mathrm{G}+\mathrm{C}\end{array}$ 


\begin{tabular}{|c|c|c|c|c|c|}
\hline \multicolumn{2}{|c|}{$\begin{array}{l}\text { Ungrouped C379 } \\
\text { strain }\end{array}$} & Listeria $\mathrm{sp}$. & $R, 96 / 52$, human faeces & $\mathrm{III} / \mathrm{V} \mathrm{VI} / \mathrm{XV} \mathrm{ABC}$ & - \\
\hline 13 & \multicolumn{2}{|c|}{$\begin{array}{l}\mathrm{C} 212^{\mathrm{T}} \dagger+\quad \text { Listeria } \\
\text { ATCC } 14870^{\mathrm{T}} \dagger \ddagger \text { denitrificans }\end{array}$} & $\begin{array}{l}\text { CIP, 55134, cooked blood } \\
\text { Cooked blood }\end{array}$ & - & $\begin{array}{l}61 \cdot 7 \\
60 \cdot 8\end{array}$ \\
\hline 14 & $\begin{array}{l}\text { ATCC } 491^{\mathrm{T}} \\
\text { NCIB } 8073^{\mathrm{T}}\end{array}$ & $\begin{array}{l}\text { Cellulomonas uda } \\
\text { Cellulomonas } \\
\text { flavigena }\end{array}$ & Soil & - & $\begin{array}{l}- \\
-\end{array}$ \\
\hline \multicolumn{2}{|c|}{$\begin{array}{l}\text { Ungrouped C399 } \\
\text { strain }\end{array}$} & Listeria $\mathrm{sp}$ & PHL $12582 / 75$, human & - & - \\
\hline 15 & $\begin{array}{l}\text { C5 } \\
\text { C6 } \\
\text { NCTC } 404\end{array}$ & \} Kurtha zopfii & $\begin{array}{l}\text { Keddie, K2, milk } \\
\text { Keddie, K8, meat }\end{array}$ & $\begin{array}{l}- \\
- \\
-\end{array}$ & $\begin{array}{l}- \\
- \\
-\end{array}$ \\
\hline 16 & $\begin{array}{l}\text { C335† } \\
\text { C338† }\end{array}$ & \} $\begin{array}{l}\text { Erysipelothrix } \\
\text { rhusiopathiae }\end{array}$ & $\begin{array}{l}\text { Sneath, } 185 \text {, mouse } \\
\text { Sneath, 182, duck }\end{array}$ & - & $\begin{array}{l}60 \cdot 2 \\
58 \cdot 2\end{array}$ \\
\hline \multirow[t]{2}{*}{$\begin{array}{l}\text { Ungrouped } \\
\text { strains }\end{array}$} & C469 & $\begin{array}{l}\text { Atypical } \\
\text { Lactobacillus }\end{array}$ & Sharpe, MT10, chicken meat & - & $37 \cdot 3$ \\
\hline & $\mathrm{C} 660$ & L. monocytogenes & P, L136, sheep & 5 & - \\
\hline \multirow[t]{2}{*}{17} & NCPPB 363 & $\begin{array}{l}\text { 'Corynebacterium } \\
\text { betae' }\end{array}$ & Red beet & - & - \\
\hline & NCPPB 844 & $\begin{array}{l}\text { 'Corynebacterium } \\
\text { poinsettiae' }\end{array}$ & Euphorbia pulcherrima & - & - \\
\hline \multirow{2}{*}{$\begin{array}{l}\text { Ungrouped } \\
\text { strain } \\
18\end{array}$} & NCPPB 797 & $\begin{array}{l}\text { 'Corynebacterium } \\
\text { rathayi' }\end{array}$ & Dactylis glomerata & - & - \\
\hline & $\begin{array}{l}\text { NCTC } 8163^{\mathrm{T}} \dagger \\
\text { C } 334 \dagger \\
\text { C337† }\end{array}$ & $\left\{\begin{array}{l}\text { E. rhusiopathiae } \\
\text { Erysipelothrix sp. }\end{array}\right.$ & $\begin{array}{l}\text { Pig } \\
\text { Sneath, 176, human } \\
\text { Sneath, 193, human }\end{array}$ & $\begin{array}{l}- \\
- \\
-\end{array}$ & $\begin{array}{l}36 \cdot 0 \\
35 \cdot 0 \\
32 \cdot 0\end{array}$ \\
\hline 19 & $\begin{array}{l}\mathrm{C} 484 \dagger \\
\mathrm{C} 485 \dagger\end{array}$ & $\left\{\begin{array}{l}\text { Atypical } \\
\text { Lactobacillus }\end{array}\right.$ & $\begin{array}{l}\text { Sharpe, MT24, chicken meat } \\
\text { Sharpe, MT25, chicken meat }\end{array}$ & - & $\begin{array}{l}38 \cdot 6 \\
38 \cdot 8\end{array}$ \\
\hline \multicolumn{2}{|c|}{$\begin{array}{l}\text { Ungrouped C524 } \\
\text { strain }\end{array}$} & Erysipelothrix sp. & PHL, pig & - & - \\
\hline \multirow[t]{4}{*}{20} & $\mathrm{C} 456$ & Lactobacillus lactis & Sharpe, (L1) & - & - \\
\hline & $\begin{array}{l}\text { NCIB } 10560^{\mathrm{T}} \dagger \\
\text { G144 }\end{array}$ & \} Lactobacillus mali & $\begin{array}{l}\text { Cider } \\
\text { Carr, 26, cider }\end{array}$ & $\begin{array}{l}- \\
-\end{array}$ & $\begin{array}{l}- \\
-\end{array}$ \\
\hline & C672† & $\begin{array}{l}\text { Lactobacillus } \\
\text { yamanashiensis }\end{array}$ & Carr, 239, wine & - & - \\
\hline & $\mathrm{C} 459$ & $\begin{array}{l}\text { Lactobacillus } \\
\text { fermenti }\end{array}$ & Sharpe, $(\mathrm{F} 1)$ & - & - \\
\hline
\end{tabular}

$T$, type strain.

* NCTC, National Collection of Type Cultures; ATCC, American Type Culture Collection; NCDO, National Collection of Dairy Organisms; NCPPB, National Collection of Plant Pathogenic Bacteria; NCIB, National Collection of Industrial Bacteria; CIP, Collection Institut Pasteur; Carr, Dr J. G. Carr, Long Ashton, Bristol; Kahn, Dr Kahn, Sutton Bonnington, Notts; Keddie, Dr R. M. Keddie, University of Reading; Kitchell, Dr A. Kitchell, Cambridge; LRI, Leicester Royal Infirmary; LTRS, Low Temperature Research Station, Cambridge; P, Dr Pritchard, Weybridge; PHL, Public Health Laboratory, Leicester; Bi, E1, Fo, Or, R, S, Dr B. Ralovich, Pécs, Hungary; Seeliger, Professor H. P. R. Seeliger, Würzburg, FRG; Sharpe, Dr M. E. Sharpe, Shinfield, Reading; Sneath, Professor P. H. A. Sneath, University of Leicester; Wat, Mr J. Watkins, Yorkshire Water Authority. Strains suffixed A, B, C and D represent replicate cultures, G and W grey and white colony forms, R and $S$ rough and smooth colony forms. Sharpe $M T$ strains suffixed $L$ and $S$ represent large and small colony forms.

† Strains examined for cell wall amino acids and isoprenoid quinones.

$\ddagger$ Listeria denitrificans has been reclassified as Jonesia denitrificans (Rocourt et al., 1987a).

treated as separate strains. Some strains of Listeria spp. were obtained from different sources and it was realised later that they were subcultures of the same strain. They were retained in the study because they had different histories and it was of interest to see what effect, if any, this had on their eventual clustering. All the strains were lyophilized and working cultures maintained by weekly subculture on Blood Agar Base no. 2(Difco). This medium was used as the basal solid medium (BM) and the same ingredients, minus agar, were used when a liquid medium was required. Normally, all tests were inoculated from overnight BM agar cultures. Unless otherwise stated, incubation was at $30^{\circ} \mathrm{C}$, since none of the $B$. thermosphacta strains grew at $37^{\circ} \mathrm{C}$.

Morphology. Cultures ( 24 and $48 \mathrm{~h}$ ) on BM agar were examined visually by low-power magnification $(\times 10)$ under a binocular microscope using reflected and transmitted light and the colony morphology was noted. These 
cultures were also inspected for pigment formation. After $2 \mathrm{~d}$ incubation, they were left in the light at room temperature for a further $9 \mathrm{~d}$, when pigment formation was determined. Smears of strains grown for 24 and $48 \mathrm{~h}$ on BM agar were prepared in saline and Gram-stained by the method of Collins \& Lyne (1970) with decolourization by acetone. Cultures $(24 \mathrm{~h})$ in BM broth incubated overnight at room temperature (about $22^{\circ} \mathrm{C}$ ) were examined for motility by the hanging drop method. Pellicle or ring formation, the presence of a deposit and ease of resuspension were examined in tubes of BM broth incubated for 24 and $48 \mathrm{~h}$.

Growth tests. Growth at different temperatures was assessed in tubes of BM broth lightly inoculated with $18 \mathrm{~h}$ cultures and incubated in water-baths maintained at $5,10,30,35,45$ and $50^{\circ} \mathrm{C} \pm 1{ }^{\circ} \mathrm{C}$. Growth was assessed by eye daily for up to $21 \mathrm{~d}\left(5^{\circ} \mathrm{C}\right), 14 \mathrm{~d}\left(10\right.$ and $\left.20^{\circ} \mathrm{C}\right)$ and up to $7 \mathrm{~d}$ for all other temperatures. Survival at $60^{\circ} \mathrm{C}$ for $15 \mathrm{~min}$ was tested by lightly inoculating tubes of BM broth (preheated to $60^{\circ} \mathrm{C}$ ) with $18 \mathrm{~h}$ cultures; the tubes were held at $60{ }^{\circ} \mathrm{C}$ for $15 \mathrm{~min}$, cooled immediately in ice-cold water, then incubated at $30^{\circ} \mathrm{C}$ and examined for growth after 1 and $2 \mathrm{~d}$. For anaerobic growth, duplicate tubes of BM broth were inoculated with $18 \mathrm{~h}$ cultures. One was incubated in an anaerobic jar under hydrogen, the other in air. Growth in both tubes was compared and recorded after $5 \mathrm{~d}$.

Growth in $\mathrm{BM}$ broth containing $\mathrm{NaCl}(6.5$ and $10 \%$ w/v) was compared with growth in $\mathrm{BM}$ broth alone after incubation for 1,2 and $7 \mathrm{~d}$. Growth on BM agar containing potassium thiocyanate $(2.5,3.75$ and $5 \%$, w/v) or thallous acetate $(0.01,0.02$ and $0.03 \%, \mathrm{w} / \mathrm{v})$ or sodium azide $(0.01,0.02$ and $0.05 \%, \mathrm{w} / \mathrm{v})$ was compared with growth on BM agar alone after incubation for 1 and $2 \mathrm{~d}$. Growth and degree of blackening on BM agar containing potassium tellurite $(0.1$ and $0.5 \%, \mathrm{w} / \mathrm{v}$; prepared by adding $10 \%, \mathrm{w} / \mathrm{v}$, potassium tellurite, sterilized by autoclaving, to sterile BM agar) were compared with that on BM agar alone at 1 and $2 \mathrm{~d}$. Growth and reduction of 2,3,5-triphenyltetrazolium chloride $(0 \cdot 01$ and $0 \cdot 1 \%, \mathrm{w} / \mathrm{v}$; prepared by adding a $10 \%$, w/v, filter-sterilized aqueous solution to sterile SBM agar) (composition given below) were compared with that on SBM agar alone at 1 and $2 \mathrm{~d}$. Sensitivity to nitrite was determined in $\mathrm{BM}$ broth containing $0.01 \%(\mathrm{w} / \mathrm{v}) \mathrm{KNO}_{2}$ dispensed in $7 \mathrm{ml}$ quantities in test-tubes. Growth was recorded after 1 and $2 \mathrm{~d}$. Growth on MRS agar (Oxoid CM 361) and Gardner's (1966) medium was assessed after 1 and $2 \mathrm{~d}$.

Acid from carbohydrates. This was tested in SBM agar which contained: peptone (Oxoid), $1 \%$ (w/v); yeast extract (Oxoid), $0.1 \%$; NaCl, 0.5\%; agar (Oxoid no. 3), 1.5\% (w/v); bromocresol purple, 0.003\% (w/v), pH 7.4. Filter-sterilized carbohydrates (with certain exceptions) were added to sterile SBM agar to give a final concentration of $0.5 \%$. The exceptions were dextrin, glycogen and starch, which were autoclaved and then added aseptically to the sterile basal medium. The media were dispensed into repli-dishes (Sterilin), inoculated with overnight cultures as described by Stevens (1969), incubated and examined for acid production after 1, 2, 3, 7, 9 and $10 \mathrm{~d}$.

Carbon source utilization. SBM broth with and without the substrate under test was dispensed in $5 \mathrm{ml}$ amounts into $4 \times 0.5$ inch $(80 \times 13 \mathrm{~mm})$ tubes. Both media were inoculated and incubated for $5 \mathrm{~d}$ after which growth in the two media was compared by measurement of absorbance at $540 \mathrm{~nm}$. Positive results were scored only when the $A_{540}$ in the medium containing the added carbon source was at least twice that in SBM broth alone.

Antibiotic sensitivities. BM agar plates were lawned with overnight broth cultures. Multodisks (Oxoid) containing appropriate antibiotics were then placed on the plates. Resistance (no inhibition zone was recorded as positive) was assessed after 1 and $2 \mathrm{~d}$.

Degradative tests. Aesculin hydrolysis was determined using SBM broth supplemented with (g $\left.1^{-1}\right)$ sodium citrate (1), aesculin (1) and ferric citrate scales ( 0.05 ). The ferric citrate scales were dissolved by boiling in a small volume of water and added to the medium before sterilization. Blackening of the medium and loss of purple sheen were recorded at 1 and $5 \mathrm{~d}$. Cellulolytic activity was investigated by inoculating strains into tubes of BM broth containing strips of Whatman no. 1 filter paper, half the length of which was above the level of the liquid. The tubes were incubated and examined for filter paper disintegration at frequent intervals for up to 10 weeks. To detect casein hydrolysis an equal volume of $10 \%(\mathrm{w} / \mathrm{v})$ skim milk (Difco) in distilled water sterilized by autoclaving was added to sterile double-strength BM agar medium. Cultures were streaked to give one line of growth, incubated and the plates examined for areas of clearing for up to $15 \mathrm{~d}$. For detection of lecithinase sterile egg yolk emulsion (Oxoid; final concentration $1 \%, \mathrm{v} / \mathrm{v}$ ) was added to cool, sterile BM agar. Cultures were streaked to give one line of growth, incubated and examined for zones of clearing and/or precipitation at 1, 2, 8 and $20 \mathrm{~d}$. Hippurate hydrolysis was detected in BM broth containing $1 \%(w / v)$ sodium hippurate. The medium was sterilized by autoclaving, dispensed in $10 \mathrm{ml}$ amounts, inoculated and incubated for $7 \mathrm{~d}$. Each culture was then centrifuged and two $1 \mathrm{ml}$ samples removed. To one was added $1 \mathrm{ml} 12 \%(\mathrm{w} / \mathrm{v}) \mathrm{FeCl}_{3} \cdot 6 \mathrm{H}_{2} \mathrm{O}$; the presence after $30 \mathrm{~min}$ of a brown precipitate indicated a positive result. To the other, $1 \mathrm{ml} 50 \%(\mathrm{v} / \mathrm{v}) \mathrm{H}_{2} \mathrm{SO}_{4}$ (Davis, 1955$)$ was added; the presence after $30 \mathrm{~min}$ of white crystals was taken as a positive result. Both test methods were used because weak positive reactions are frequently detected only by the $\mathrm{H}_{2} \mathrm{SO}_{4}$ method. To detect gelatin hydrolysis tubes of BM broth containing $12 \%(\mathrm{w} / \mathrm{v})$ gelatin (Difco) were stab-inoculated and then inspected at frequent intervals for $14 \mathrm{~d}$. Tubes were refrigerated at $4{ }^{\circ} \mathrm{C}$ for $1 \mathrm{~h}$ before inspection. Hydrolysis of starch was determined using BM agar containing $2 \%(w / v)$ starch. After $15 \mathrm{~d}$ incubation plates were flooded with iodine solution and examined for zones of clearing. DNAase and RNAase were detected on $\mathrm{BM}$ agar containing $0.08 \%(\mathrm{w} / \mathrm{v}) \mathrm{CaCl} \mathrm{Cl}_{2}$ and $0.2 \%(\mathrm{w} / \mathrm{v})$ DNA (BDH) or RNA (BDH). After $6 \mathrm{~d}$ incubation the plates were flooded with $1 \mathrm{M}-\mathrm{HCl}$ and 
inspected for zones of clearing. Hydrolysis of Tweens 20, 40, 60 and 80 (Sigma; $1 \%, v / v$, in BM agar) was recorded at frequent intervals for up to $20 \mathrm{~d}$ as zones of precipitation and/or clearing. Phosphatase and sulphatase activities were determined using a $1 \%(\mathrm{w} / \mathrm{v})$ aqueous solution of phenolphthalein diphosphate (sodium salt, BDH) or phenolphthalein disulphate (potassium salt, Koch-Light), sterilized by filtration and added to sterile molten BM agar to give a final concentration of $0.001 \%(w / v)$. After $6 \mathrm{~d}$ incubation, $1 \mathrm{ml}$ concentrated ammonia solution was placed in the lid of each inverted dish and allowed to stand for $10 \mathrm{~min}$. A positive reaction was indicated by the appearance of a pink colour around the bacterial growth. Tyrosine and xanthine hydrolysis were detected in BM agar containing $0.5 \%(\mathrm{w} / \mathrm{v})$ L-tyrosine (Sigma) or $0.5 \%(\mathrm{w} / \mathrm{v})$ xanthine (Sigma), autoclaved and dispensed into Petri dishes. Plates were single-streaked and inspected for zones of clearing at frequent intervals for up to $21 \mathrm{~d}$. Urease activity was detected in a medium consisting of $50 \mathrm{ml} \mathrm{40 \% (w/v)} \mathrm{urea} \mathrm{(sterilized} \mathrm{by} \mathrm{filtration)} \mathrm{added} \mathrm{to}$ 1 litre sterile molten BM agar, with phenol red $(0.012 \mathrm{~g})$ as indicator. This was dispensed in $10 \mathrm{ml}$ quantities into test-tubes and allowed to set as slants. After inoculation the tubes were inspected at frequent intervals for up to $21 \mathrm{~d}$ for development of a red colour.

Miscellaneous tests. Haemolysis was detected in layered plates prepared by pouring $10 \mathrm{ml}$ sterile BM agar into Petri dishes; after this had set, a layer $(10 \mathrm{ml})$ of cooled, sterile BM agar containing $7 \cdot 5 \%(\mathrm{v} / \mathrm{v})$ horse blood was added. Plates were streaked to obtain single colonies and examined for $\beta$-haemolysis after 24 and $48 \mathrm{~h}$. To detect catalase colonies of an overnight BM agar culture were flooded with $20 \mathrm{vol} . \mathrm{H}_{2} \mathrm{O}_{2}$ and observed for the production of effervescence for up to $5 \mathrm{~min}$. To detect oxidase growth from an overnight BM agar culture was rubbed on Whatman no. 1 filter paper previously soaked in oxidase reagent (Cowan, 1974; solution 1) and observed for the development of a purple colour for up to $10 \mathrm{~s}$ (Kovacs, 1956). Oxidation/fermentation of glucose was assessed in tubes of BM broth plus glucose $(0.5 \%, \mathrm{w} / \mathrm{v})$, agar (Oxoid no. $3 ; 0.4 \%, \mathrm{w} / \mathrm{v})$ and bromocresol purple $(0.003 \%, \mathrm{w} / \mathrm{v})$. The tubes were inoculated and incubated according to the method of Hugh \& Leifson (1953). Gas production from glucose was assessed in SBM broth containing $0.5 \%(\mathrm{w} / \mathrm{v})$ glucose, dispensed $(4 \mathrm{ml})$ into $4 \times 0.5 \mathrm{inch}(80 \times 13 \mathrm{~mm})$ test tubes containing inverted Durham tubes. The inoculated tubes were examined for the production of gas at 1,2 , 5 and $7 \mathrm{~d}$. Gluconate oxidation was assessed in tubes of SBM broth containing $1 \%(\mathrm{w} / \mathrm{v})$ sodium gluconate. These were inoculated and incubated for $3 \mathrm{~d}$; a Clinitest tablet (Ames) was then added to $0.5 \mathrm{ml}$ of the growth medium. A positive result was indicated by the formation of an orange to brown colour. For the methyl red and VogesProskauer tests BM broth containing $0.5 \%(\mathrm{w} / \mathrm{v})$ glucose and $0.5 \%(\mathrm{w} / \mathrm{v}) \mathrm{K}_{2} \mathrm{HPO}_{4}, \mathrm{pH} 7 \cdot 5$, was dispensed in $12.5 \mathrm{ml}$ amounts into $25 \mathrm{ml}$ capacity screw-capped bottles, inoculated and incubated for $7 \mathrm{~d}$. After 3 and $7 \mathrm{~d}$ portions were removed and the methyl red test was done as described by Cowan (1974); the Voges-Proskauer test was done after $7 \mathrm{~d}$ according to method 1 of Cowan (1974). Ammonia production from peptone was detected using SBM agar containing bromocresol purple $(0.003 \%)$. This was dispensed into repli-dishes and inoculated as described by Stevens (1969). Dishes were examined for the appearance of a deep purple colour at frequent intervals for up to $10 \mathrm{~d}$. Indole production from tryptone was assessed in medium containing $\left(\mathrm{g}^{-1}\right)$ tryptone (Oxoid) (15) plus yeast extract (Oxoid) (1), dispensed into test-tubes in $10 \mathrm{ml}$ quantities. After inoculation the broths were incubated for $16 \mathrm{~d}$ and tested by method 2 of Cowan (1974). Hydrogen sulphide production was detected on slants of $\mathrm{BM}$ agar supplemented with $0.05 \%(w / v)$ cysteine hydrochloride (BDH). These were inoculated and then strips of lead acetate paper were inserted under the cap so that they hung into the tube. The tubes were examined for blackening of the lead acetate paper at frequent intervals for up to $21 \mathrm{~d}$. Arginine deamination was detected by the method of Thornley (1960) with SBM broth as the basal medium. Tests were done with and without a sterile liquid paraffin layer. Results were recorded at 2 and $20 \mathrm{~d}$.

Coding of characters. The data were coded as characters with either two or three states. The two-state characters were coded as positive (1) and negative ( 0 ). The three-state characters were coded as strongly positive (2), weakly positive (1) and negative (0). Ten tests which were of no discriminatory value were excluded from the data set. Tests to assess growth on MRS medium and Gardner's medium were not included in the coded data because not all the strains were tested. The results are given separately where appropriate.

Computation. All computing was done on the University of Nottingham ICL 1900 computer, except for the phenograms which were produced on the University of Leicester CDC CYBER 72 using the TAXPAK program written by M. J. Sackin. Gower's similarity coefficient $\left(S_{G}\right)$ (Gower, 1971) was computed and clustering achieved by unweighted pair group average linkage (UPGMA) and single linkage methods (Sneath \& Sokal, 1973).

The data were also converted to two-state character form by combining 'strongly positive' and 'weakly positive' into a single 'positive' state scored as 1 , with two-state characters unchanged. The simple matching coefficient $\left(S_{S M}\right)$ and the pattern difference coefficient $\left(D_{P}\right)$ (Sneath \& Sokal, 1973) were then computed on the converted data, and both similarity matrices were clustered by the same two methods. For every clustering, the cophenetic correlation was computed for the dendrogram and similarity matrix from which it was derived.

The IGROUPS (Integer Groups) program printed character value statistics on specified groups of OTUs chosen from the sorted matrix. Overlap statistics were computed by means of the OVCLUST program (Sneath, 1979). The program was run on data for every pair of clusters using the intercentroid distance $(D)$ between each pair of clusters and the standard deviation $\left(s_{q}\right)$ of the $q$-distributions of each cluster of the pair. The $D$ and $s$ values were obtained from a revised IGROUPS program. The chosen overlap used was $5 \%$. 
Cell wall analyses. Most bacteria were grown on BAB2 (Difco) agar plates, incubated at $30^{\circ} \mathrm{C}$ for $24 \mathrm{~h}$. Lactobacillus strains were grown on MRS (Oxoid) agar plates and Erysipelothrix strains in $20 \mathrm{ml}$ amounts of Brain Heart Infusion broth (Oxoid). Fully hydrolysed cell walls were prepared from about $10 \mathrm{mg}$ wet wt of cells by the hot trichloroacetic acid rapid screening method of Schleifer \& Kandler (1972). The amino acid composition of complete hydrolysates was determined using an automatic amino acid analyser.

Extraction and analysis of fatty acids and mycolic acids. Selected strains of Brochothrix and Listeria and atypical erysipelothrix were grown in Brain Heart Infusion broth (Oxoid) with shaking at $30^{\circ} \mathrm{C}$. Cultures were checked for purity at maximum growth, harvested by centrifugation and freeze dried. Fatty acids and mycolic acids were examined using the whole organism methanolysis procedure of Minnikin et al. (1975). Fatty acid methyl esters were analysed by GLC (Collins \& Jones, 1980).

Extraction and analysis of isoprenoid quinones. Bacteria were grown as described for fatty acid analyses. Isoprenoid quinones were extracted and purified as described by Collins et al. (1977) from about $100 \mathrm{mg}$ dried cells and were further examined by reverse-phase partition chromatography (Collins et al., 1980). Mass spectra of the purified quinones were recorded on an AEI MS9 instrument using a direct insertion probe, an ionizing voltage of $70 \mathrm{eV}$ and a temperature range of $180-200^{\circ} \mathrm{C}$.

Cytochrome composition. Listeria strains only were examined for the presence of cytochromes. Cells were grown in Brain Heart Infusion broth (Oxoid) at $30^{\circ} \mathrm{C}$ with shaking for $18 \mathrm{~h}$, harvested by centrifugation, washed once in distilled water, and frozen overnight at $-70^{\circ} \mathrm{C}$. Cytochrome composition was determined by the procedures of Jones \& Redfearn (1966, 1967).

DNA base composition determinations. Representative strains of Brochothrix and Listeria and some atypical erysipelothrix strains were grown in Brain Heart Infusion broth (Oxoid) supplemented with $0.5 \%$ glycine (Fisons) with shaking at $30^{\circ} \mathrm{C}$. Atypical lactobacilli were grown in the same medium in stationary culture at $30^{\circ} \mathrm{C}$. Cells were harvested after 12-16 h incubation when in the late exponential or early stationary phase of growth. The method of Garvie (1976) was used for the isolation and purification of the DNA. DNA base composition was estimated by thermal denaturation in standard saline citrate (with the exception of three strains which were examined in dilute saline citrate) by the method of Garvie (1978) but using a Gilford model 240 spectrophotometer.

\section{RESULTS}

\section{Numerical taxonomy}

Reproducibility. The similarity between duplicate strains varied from $95.7 \%$ to $99 \cdot 6 \% \mathrm{~S}$, with a mean of approximately $98 \% \mathrm{~S}$. This indicates an estimated mean error in testing of $0.975 \%$. The test error was studied by repeating 30 tests (resulting in 33 characters) for all strains and comparing the two sets of data. The reproducibility obtained varied from $100 \%$ to $73 \%$. Sneath \& Johnson (1972) have suggested that tests showing errors in reproducibility of $10-15 \%$ are acceptable. Twelve test characters fell below the $90 \%$ reproducibility level and only six below the $85 \%$ reproducibility level. Thus, on the whole, both reproducibility between duplicate strains and the reproducibility of tests was good and compared well with figures obtained in other similar studies.

Cluster analysis. (Tables 1 and 2; Fig. 1.) The results of the different computations gave broadly similar groupings. The classification which resulted from the UPGMA clustering of the $S_{G}$ coefficient (Fig. 1) gave the highest cophenetic correlation value (0.94) and the interpretation of the data will be confined mainly to this computation.

All the strains joined at a similarity $\left(\% S_{G}\right)$ value of 62 . The majority of the strains clustered into 20 phenons of very unequal size. The characteristics of the majority of the phenons are listed in Table 2.

With the exception of four strains received as Listeria spp. (C454, C379, C399 and C660) and the two cultures of $L$. denitrificans, all strains of Listeria clustered in phenons 1 to 6 (overall similarity $80 \%$ ) or were closely associated with these phenons.

Phenons 1 to 5, L. monocytogenes, L. innocua, L. ivanovii and Listeria spp. joined at $88 \% S$ (Fig. 1). Phenon 1, which contained the type strain (NCTC 10357), can be equated with the species $L$. monocytogenes. Phenon 2 also contained strains that have the properties of this species and like phenon 1 contained haemolytic and non-haemolytic forms. The seven unclustered strains (C343, C363, C374, C351, C361, C364 and C197) were very closely related to phenons 1 and 2, and were non-haemolytic. Phenon 3 contained 58 strains including the type strain of $L$. innocua and all were non-haemolytic. With the exception of the production of acid from xylose by three strains, 


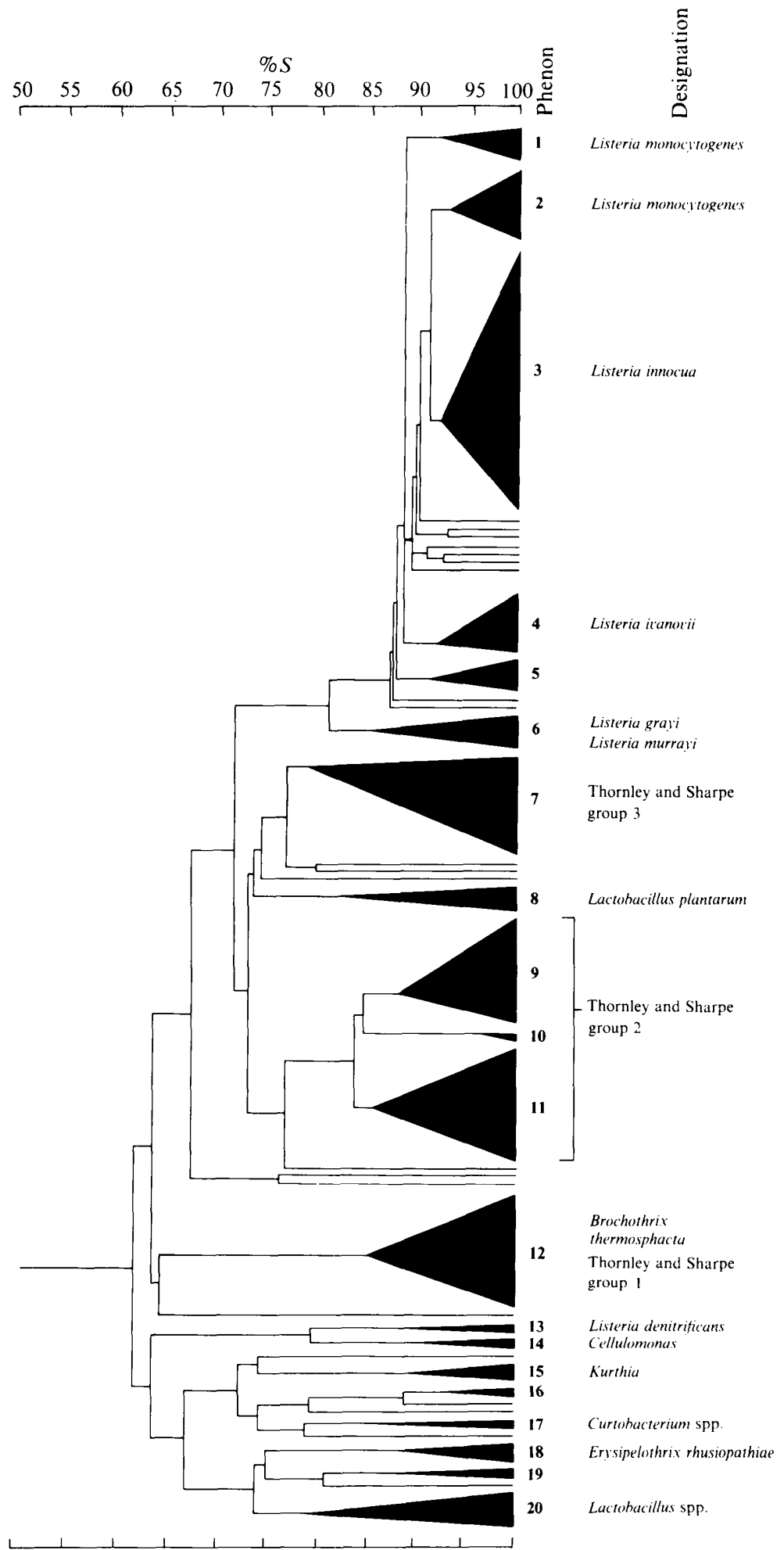

Fig. 1. Simplified phenogram showing clusters obtained with $S_{G}$ coefficient and average linkage algorithm (cophenetic correlation 0.94). 
Table 2. Characteristics of the majority of the phenons in Fig. I as the percentage positive

All strains were easy to emulsify and grew well at 10,20 and $30^{\circ} \mathrm{C}$. None produced ammonia from peptone, gas from glucose, indole from tryptone, gas from nitrate, oxidized gluconate, utilized exogenous citrate, produced sulphatase, or degraded gelatine, tyrosine or xanthine.

$\begin{array}{llllllllllllll}\text { Phenon no. ... } & 1-5^{*} & 6 & 7 & 8 & 9 & 10 & 11 & 12 & 13 & 14 & 15 & 16 & 18\end{array}$

$\begin{array}{llllllllllllll}\text { No. of strains ... } & 99 & 5 & 13 & 4 & 14 & 2 & 15 & 15 & 2 & 2 & 3 & 2 & 3\end{array}$

Morphology

Colony surface smooth

Colony margin entire

Colony elevation convex

Pigmentation (grey/buff)

Translucent colony

Presence of two types of colony

Gram-positive granules in

Gram-negative cells

Chain formation

Filaments

Short rods/coccobacilli

Motility

$\begin{array}{rrrrrrrrrrrrr}99 & 100 & 100 & 100 & 100 & 100 & 100 & 0 & 100 & 100 & 0 & 100 & 100 \\ 95 & 100 & 100 & 100 & 100 & 100 & 100 & 0 & 100 & 100 & 0 & 100 & 100 \\ 100 & 100 & 100 & 100 & 100 & 100 & 100 & 0 & 100 & 100 & 0 & 100 & 100 \\ 100 & 100 & 100 & 100 & 100 & 100 & 100 & 100 & 0 & 0 & 0 & 100 & 100 \\ 100 & 100 & 100 & 100 & 100 & 100 & 100 & 0 & 0 & 0 & 0 & 100 & 100 \\ 0 & 0 & 62 & 0 & 0 & 0 & 0 & 100 & 0 & 0 & 100 & 0 & 0 \\ 0 & 0 & 0 & 0 & 0 & 0 & 0 & 0 & 0 & 0 & 100 & 0 & 0\end{array}$

Growth at:

$5{ }^{\circ} \mathrm{C}(7 \mathrm{~d})$

$5^{\circ} \mathrm{C}(21 \mathrm{~d})$

$35^{\circ} \mathrm{C}$

$45^{\circ} \mathrm{C}$

$50{ }^{\circ} \mathrm{C}$

Acid production from:

Glycerol

Rhamnose

Galactose

Sucrose

Sorbitol

Fructose

Xylose

Trehalose

Raffinose

Melezitose

Inulin

Inositol

Dulcitol

Lactose

Methyl-D-glucoside

Melibiose

Salicin

Adonitol

Arabinose

Mannitol

Maltose

Cellobiose

Glycogen

Starch

Dextrin

Erythritol

Mannose

Glucose

Glucose utilization

Oxidative

Fermentative

Growth under $\mathrm{H}_{2}$

$\begin{array}{rrrrrrrrrrrrr}7 & 0 & 0 & 25 & 0 & 0 & 0 & 100 & 0 & 100 & 100 & 0 & 0 \\ 5 & 0 & 0 & 0 & 0 & 0 & 0 & 93 & 0 & 0 & 100 & 0 & 0 \\ 100 & 100 & 100 & 100 & 50 & 100 & 73 & 100 & 100 & 100 & 100 & 0 & 100 \\ 100 & 100 & 100 & 0 & 0 & 0 & 13 & 0 & 100 & 100 & 100 & 0 & 0 \\ & & & & & & & & & & & & \\ 96 & 100 & 100 & 100 & 100 & 100 & 100 & 100 & 50 & 100 & 100 & 0 & 100 \\ 100 & 100 & 100 & 100 & 100 & 100 & 100 & 100 & 50 & 100 & 100 & 100 & 100 \\ 100 & 100 & 100 & 100 & 100 & 100 & 100 & 0 & 100 & 100 & 100 & 100 & 100 \\ 98 & 100 & 77 & 100 & 93 & 100 & 87 & 0 & 50 & 100 & 100 & 0 & 0 \\ 22 & 20 & 46 & 100 & 86 & 50 & 47 & 0 & 50 & 100 & 33 & 0 & 0\end{array}$

Growth on sole carbon sources

Glucose

Pyruvate

$\begin{array}{lllllllllllll}98 & 100 & 15 & 75 & 100 & 0 & 100 & 100 & 100 & 50 & 0 & 0 & 0\end{array}$

$\begin{array}{rrrrrrrrrrrrr}73 & 60 & 8 & 50 & 21 & 0 & 7 & 60 & 0 & 0 & 0 & 0 & 0\end{array}$

$\begin{array}{lllllllllllll}11 & 100 & 92 & 100 & 86 & 100 & 53 & 100 & 100 & 100 & 0 & 0 & 33\end{array}$

$\begin{array}{rrrrrrrrrrrrr}2 & 60 & 100 & 50 & 100 & 100 & 100 & 100 & 100 & 100 & 0 & 0 & 0\end{array}$

$\begin{array}{rrrrrrrrrrrrr}12 & 60 & 8 & 75 & 64 & 0 & 13 & 87 & 0 & 0 & 0 & 0 & 0\end{array}$

$\begin{array}{rrrrrrrrrrrrr}100 & 100 & 100 & 100 & 100 & 100 & 100 & 100 & 100 & 100 & 0 & 0 & 100\end{array}$

$\begin{array}{lllllllllllll}15 & 60 & 0 & 0 & 0 & 100 & 0 & 93 & 100 & 100 & 0 & 0 & 0\end{array}$

$\begin{array}{lllllllllllll}90 & 100 & 100 & 75 & 100 & 100 & 100 & 100 & 100 & 100 & 0 & 0 & 0\end{array}$

$\begin{array}{rrrrrrrrrrrrr}2 & 60 & 0 & 50 & 42 & 0 & 0 & 93 & 0 & 0 & 0 & 0 & 0\end{array}$

$\begin{array}{lllllllllllll}34 & 0 & 0 & 75 & 93 & 100 & 53 & 87 & 0 & 0 & 0 & 0 & 0\end{array}$

$\begin{array}{rrrrrrrrrrrrr}0 & 60 & 8 & 0 & 100 & 0 & 0 & 87 & 0 & 50 & 0 & 0 & 0\end{array}$

$\begin{array}{rrrrrrrrrrrrr}0 & 0 & 0 & 0 & 79 & 0 & 27 & 100 & 0 & 0 & 0 & 0 & 0 \\ 0 & 0 & 0 & 0 & 0 & 0 & 0 & 87 & 0 & 0 & 0 & 0 & 0\end{array}$

$\begin{array}{lllllllllllll}86 & 100 & 54 & 100 & 93 & 100 & 47 & 100 & 100 & 100 & 0 & 0 & 33\end{array}$

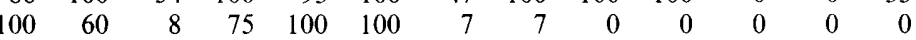

$\begin{array}{lllllllllllll}0 & 60 & 0 & 50 & 43 & 0 & 0 & 73 & 100 & 0 & 0 & 0 & 0\end{array}$

$\begin{array}{lllllllllllll}100 & 100 & 92 & 100 & 100 & 100 & 100 & 100 & 100 & 100 & 0 & 0 & 0\end{array}$

$\begin{array}{rrrrrrrrrrrrr}4 & 0 & 0 & 0 & 0 & 0 & 0 & 7 & 0 & 0 & 0 & 0 & 0\end{array}$

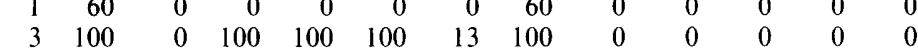

$\begin{array}{rrrrrrrrrrrrr}84 & 100 & 100 & 100 & 100 & 100 & 100 & 100 & 100 & 100 & 0 & 50 & 0\end{array}$

$\begin{array}{rrrrrrrrrrrrr}100 & 100 & 100 & 100 & 100 & 100 & 100 & 100 & 100 & 100 & 0 & 0 & 0\end{array}$

$\begin{array}{lllllllllllll}2 & 60 & 0 & 0 & 0 & 0 & 0 & 80 & 100 & 100 & 0 & 0 & 0 \\ 4 & 60 & 0 & 0 & 0 & 0 & 0 & 87 & 100 & 100 & 0 & 0 & 0\end{array}$

$\begin{array}{rrrrrrrrrrrrr}16 & 100 & 69 & 25 & 100 & 100 & 100 & 100 & 100 & 100 & 0 & 0 & 0\end{array}$

$\begin{array}{lllllllllllll}1 & 60 & 0 & 0 & 0 & 0 & 0 & 0 & 0 & 0 & 0 & 0 & 0\end{array}$

$\begin{array}{rrrrrrrrrrrrr}100 & 100 & 100 & 100 & 100 & 100 & 100 & 100 & 100 & 100 & 0 & 0 & 0 \\ 100 & 100 & 100 & 100 & 100 & 100 & 100 & 100 & 100 & 100 & 0 & 0 & 67\end{array}$

$\begin{array}{lllllllllllll}100 & 100 & 100 & 100 & 100 & 100 & 100 & 100 & 100 & 100 & 0 & 0 & 100\end{array}$

$\begin{array}{lllllllllllll}100 & 100 & 100 & 100 & 100 & 100 & 100 & 100 & 100 & 100 & 0 & 0 & 100\end{array}$

$\begin{array}{lllllllllllll}100 & 100 & 100 & 100 & 100 & 100 & 100 & 100 & 50 & 100 & 100 & 100 & 100\end{array}$

Malate

$\begin{array}{lllllllllllll}100 & 100 & 100 & 100 & 100 & 100 & 100 & 100 & 100 & 0 & 0 & 0 & 33\end{array}$

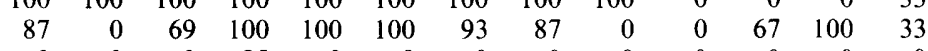


Table 2 (continued)

\begin{tabular}{|c|c|c|c|c|c|c|c|c|c|c|c|c|c|}
\hline $\begin{array}{r}\text { Phenon no. } \ldots \\
\text { No. of strains } \ldots\end{array}$ & $\begin{array}{c}1-5^{*} \\
99\end{array}$ & $\begin{array}{l}6 \\
5\end{array}$ & $\begin{array}{r}7 \\
13\end{array}$ & $\begin{array}{l}8 \\
4\end{array}$ & $\begin{array}{r}9 \\
14\end{array}$ & $\begin{array}{r}10 \\
2\end{array}$ & $\begin{array}{l}11 \\
15\end{array}$ & $\begin{array}{l}12 \\
15\end{array}$ & $\begin{array}{r}13 \\
2\end{array}$ & $\begin{array}{r}14 \\
2\end{array}$ & $\begin{array}{r}15 \\
3\end{array}$ & $\begin{array}{r}16 \\
2\end{array}$ & 18 \\
\hline \multicolumn{14}{|l|}{ Growth in presence of $(\%, w / v)$ : } \\
\hline Nitrite $(0 \cdot 1)$ & 96 & 100 & 100 & 100 & 100 & 100 & 100 & 100 & 100 & 100 & 100 & 100 & 100 \\
\hline Potassium tellurite $(0 \cdot 1)$ & 100 & 100 & 92 & 100 & 100 & 100 & 100 & 100 & 50 & 100 & 0 & 0 & 100 \\
\hline Potassium tellurite $(0 \cdot 5)$ & 100 & 100 & 85 & 50 & 100 & 100 & 100 & 73 & 50 & 0 & 0 & 0 & 100 \\
\hline Potassium thiocyanate $(2 \cdot 5)$ & 100 & 100 & 92 & 100 & 100 & 100 & 100 & 100 & 100 & 100 & 100 & 100 & 100 \\
\hline Potassium thiocyanate $(3.75)$ & 100 & 100 & 92 & 25 & 100 & 0 & 80 & 80 & 100 & 50 & 100 & 100 & 100 \\
\hline Potassium thiocyanate $(5 \cdot 0)$ & 100 & 100 & 92 & 0 & 71 & 100 & 53 & 73 & 100 & 50 & 100 & 100 & 100 \\
\hline Sodium azide $(0 \cdot 01)$ & 80 & 80 & 100 & 75 & 100 & 100 & 100 & 100 & 100 & 100 & 100 & 100 & 100 \\
\hline Sodium azide $(0.02)$ & 63 & 80 & 100 & 75 & 100 & 100 & 100 & 73 & 50 & 50 & 100 & 100 & 100 \\
\hline Sodium azide $(0.05)$ & 26 & 40 & 92 & 75 & 93 & 100 & 60 & 60 & 50 & 0 & 67 & 0 & 100 \\
\hline Sodium chloride $(6 \cdot 5)$ & 100 & 100 & 92 & 75 & 100 & 100 & 100 & 100 & 100 & 100 & 100 & 100 & 0 \\
\hline Sodium chloride (10) & 100 & 100 & 62 & 0 & 100 & 0 & 100 & 100 & 100 & 50 & 67 & 100 & 0 \\
\hline Tetrazolium $(0 \cdot 01)$ & 100 & 100 & 100 & 75 & 100 & 100 & 100 & 100 & 100 & 100 & 67 & 100 & 100 \\
\hline Tetrazolium $(0 \cdot 1)$ & 100 & 100 & 23 & 25 & 100 & 100 & 100 & 100 & 100 & 0 & 67 & 0 & 0 \\
\hline Thallous acetate $(0.01)$ & 100 & 100 & 100 & 100 & 100 & 100 & 100 & 100 & 100 & 100 & 100 & 0 & 100 \\
\hline Thallous acetate $(0.02)$ & 100 & 100 & 100 & 100 & 100 & 100 & 100 & 100 & 100 & 50 & 67 & 0 & 100 \\
\hline Thallous acetate $(0.03)$ & 100 & 100 & 100 & 100 & 100 & 100 & 100 & 100 & 0 & 100 & 100 & 0 & 100 \\
\hline \multicolumn{14}{|l|}{ Reduction of $(\%, w / v)$ : } \\
\hline Potassium tellurite $(0 \cdot 1)$ & 99 & 100 & 85 & 0 & 100 & 100 & 100 & 33 & 0 & 0 & 0 & 0 & 100 \\
\hline Potassium tellurite $(0.5)$ & 91 & 100 & 0 & 0 & 100 & 100 & 93 & 33 & 0 & 0 & 0 & 0 & 100 \\
\hline Tetrazolium $(0 \cdot 01)$ & 100 & 100 & 85 & 0 & 100 & 100 & 100 & 100 & 100 & 0 & 67 & 0 & 0 \\
\hline Tetrazolium $(0 \cdot 1)$ & 94 & 60 & 0 & 0 & 100 & 100 & 100 & 73 & 0 & 0 & 67 & 0 & 0 \\
\hline \multicolumn{14}{|l|}{ Degradation of: } \\
\hline Aesculin & 100 & 100 & 0 & 100 & 100 & 50 & 100 & 33 & 0 & 50 & 0 & 0 & 0 \\
\hline Cellulose & 0 & 0 & 0 & 0 & 0 & 0 & 0 & 0 & 50 & 100 & 0 & 0 & 0 \\
\hline DNA & 96 & 100 & 92 & 50 & 100 & 100 & 100 & 93 & 100 & 100 & 100 & 0 & 67 \\
\hline RNA & 100 & 100 & 92 & 25 & 93 & 100 & 93 & 93 & 100 & 100 & 100 & 0 & 100 \\
\hline Hippurate & 100 & 0 & 8 & 75 & 0 & 0 & 40 & 0 & 0 & 0 & 0 & 0 & 0 \\
\hline Starch (aerobic) & 11 & 0 & 85 & 25 & 0 & 0 & 0 & 0 & 100 & 100 & 0 & 0 & 0 \\
\hline Starch (anaerobic) & 5 & 0 & 69 & 25 & 0 & 0 & 0 & 0 & 100 & 100 & 0 & 0 & 0 \\
\hline Tween $20(7 \mathrm{~d})$ & 69 & 20 & 0 & 0 & 0 & 100 & 27 & 0 & 100 & 100 & 100 & 0 & 0 \\
\hline Tween $20(14 \mathrm{~d})$ & 97 & 100 & 0 & 0 & 0 & 100 & 33 & 0 & 100 & 100 & 100 & 100 & 0 \\
\hline Tween $40(7 \mathrm{~d})$ & 98 & 20 & 54 & 0 & 50 & 100 & 40 & 0 & 0 & 0 & 100 & 0 & 0 \\
\hline Tween $40(14 \mathrm{~d})$ & 100 & 40 & 77 & 0 & 57 & 100 & 60 & 0 & 100 & 100 & 100 & 0 & 0 \\
\hline Tween $60(7 \mathrm{~d})$ & 99 & 0 & 38 & 0 & 50 & 100 & 60 & 0 & 50 & 50 & 100 & 100 & 0 \\
\hline Tween $60(14 d)$ & 100 & 40 & 85 & 25 & 57 & 100 & 60 & 13 & 50 & 50 & 100 & 100 & 67 \\
\hline Tween $80(7 \mathrm{~d})$ & 39 & 0 & 0 & 0 & 0 & 0 & 0 & 0 & 0 & 50 & 67 & 100 & 0 \\
\hline Tween $80(14 \mathrm{~d})$ & 98 & 0 & 0 & 0 & 0 & 0 & 3 & 0 & 0 & 50 & 67 & 100 & 0 \\
\hline Urea & 0 & 0 & 0 & 0 & 0 & 0 & 0 & 0 & 0 & 100 & 100 & 0 & 0 \\
\hline \multicolumn{14}{|l|}{ Enzyme activity } \\
\hline$\beta$-Haemolysis & 16 & 0 & 0 & 0 & 0 & 0 & 0 & 0 & 0 & 0 & 0 & 0 & 0 \\
\hline Catalase & 100 & 100 & 0 & 50 & 0 & 0 & 0 & 100 & 100 & 100 & 100 & 100 & 0 \\
\hline Oxidase & 0 & 0 & 0 & 0 & 0 & 0 & 0 & 0 & 100 & 0 & 0 & 0 & 0 \\
\hline Casein hydrolysis & 100 & 100 & 8 & 100 & 100 & 100 & 40 & 100 & 50 & 50 & 0 & 0 & 0 \\
\hline Lecithinase & 24 & 0 & 0 & 0 & 0 & 0 & 0 & 0 & 0 & 50 & 0 & 0 & 0 \\
\hline Arginine deamination & 1 & 0 & 100 & 25 & 100 & 100 & 100 & 20 & 0 & 50 & 0 & 0 & 100 \\
\hline Phosphatase & 100 & 100 & 0 & 0 & 0 & 0 & 0 & 100 & 0 & 0 & 67 & 0 & 0 \\
\hline Nitrate reduction & 0 & 40 & 0 & 0 & 0 & 0 & 0 & 0 & 100 & 100 & 0 & 0 & 0 \\
\hline Methyl red test & 100 & 100 & 100 & 100 & 100 & 100 & 100 & 100 & 100 & 0 & 0 & 0 & 33 \\
\hline Voges-Proskauer test & 99 & 100 & 0 & 0 & 100 & 0 & 73 & 20 & 0 & 0 & 0 & 0 & 33 \\
\hline $\begin{array}{l}\text { Hydrogen sulphide } \\
\text { production }\end{array}$ & 0 & 40 & 0 & 0 & 0 & 0 & 0 & 0 & 50 & 100 & 100 & 0 & 100 \\
\hline \multicolumn{14}{|l|}{ Sensitivity to: $\uparrow$} \\
\hline Gentamycin $(10 \mu \mathrm{g})$ & 100 & 100 & 100 & 100 & 0 & 0 & 80 & 100 & 100 & 100 & 100 & 100 & 0 \\
\hline Kanamycin $(30 \mu \mathrm{g})$ & 100 & 100 & 100 & 75 & 0 & 0 & 33 & 100 & 100 & 100 & 100 & 100 & 33 \\
\hline Nalidixic acid $(30 \mu \mathrm{g})$ & 1 & 0 & 0 & 0 & 0 & 0 & 0 & 0 & 0 & 0 & 0 & 0 & 0 \\
\hline Nitrofurantoin $(200 \mu \mathrm{g})$ & 100 & 100 & 100 & 0 & 100 & 100 & 100 & 100 & 100 & 0 & 100 & 50 & 67 \\
\hline Polymyxin B (300 i.u.) & 15 & 100 & 100 & 25 & 0 & 0 & 7 & 100 & 100 & 100 & 100 & 100 & 0 \\
\hline Furazolidone $(100 \mu \mathrm{g})$ & 100 & 100 & 54 & 0 & 100 & 100 & 33 & 80 & 0 & 0 & 100 & 33 & 67 \\
\hline Carbenicillin $(10 \mu \mathrm{g})$ & 100 & 100 & 100 & 75 & 43 & 100 & 33 & 100 & 100 & 100 & 100 & 100 & 100 \\
\hline Colistin sulphate $(10 \mu \mathrm{g})$ & 1 & 20 & 15 & 25 & 7 & 0 & 0 & 80 & 0 & 50 & 100 & 0 & 33 \\
\hline
\end{tabular}


Table 2 (continued)

\begin{tabular}{|c|c|c|c|c|c|c|c|c|c|c|c|c|c|}
\hline $\begin{array}{r}\text { Phenon no. ... } \\
\text { No. of strains } \ldots\end{array}$ & $\begin{array}{c}1-5^{*} \\
99\end{array}$ & $\begin{array}{l}6 \\
5\end{array}$ & $\begin{array}{r}7 \\
13\end{array}$ & $\begin{array}{l}8 \\
4\end{array}$ & $\begin{array}{r}9 \\
14\end{array}$ & $\begin{array}{r}10 \\
2\end{array}$ & $\begin{array}{l}11 \\
15\end{array}$ & $\begin{array}{l}12 \\
15\end{array}$ & $\begin{array}{r}13 \\
2\end{array}$ & $\begin{array}{r}14 \\
2\end{array}$ & $\begin{array}{r}15 \\
3\end{array}$ & $\begin{array}{r}16 \\
2\end{array}$ & \\
\hline Erythromycin $(10 \mu \mathrm{g})$ & 100 & 100 & 100 & 100 & 100 & 100 & 87 & 100 & 100 & 100 & 100 & 100 & \\
\hline Methicillin $(10 \mu \mathrm{g})$ & 86 & 100 & 100 & 25 & 7 & 50 & 0 & 0 & 100 & 100 & 100 & 100 & \\
\hline Novobiocin $(30 \mu \mathrm{g})$ & 99 & 100 & 100 & 75 & 71 & 100 & 47 & 100 & 100 & 00 & 100 & 00 & \\
\hline Oleandomycin $(10 \mu \mathrm{g})$ & 100 & 100 & 100 & 100 & 100 & 100 & 80 & 100 & 100 & 100 & 100 & 100 & 00 \\
\hline Penicillin G (5 i.u.) & 100 & 100 & 100 & 25 & 71 & 100 & 27 & 100 & 100 & 100 & 100 & 100 & 00 \\
\hline Sulphafuraxole $(500 \mu \mathrm{g})$ & 4 & 0 & 8 & 0 & 0 & 0 & 0 & 7 & 100 & 100 & 33 & 0 & \\
\hline $\mathrm{n}(25 \mu \mathrm{g})$ & 100 & 100 & 100 & 100 & 64 & 100 & 40 & 100 & 100 & 100 & 100 & 100 & 00 \\
\hline $5 \mu \mathrm{g})$ & 90 & 100 & 31 & 0 & 0 & 0 & 20 & 13 & 50 & 50 & 100 & 100 & \\
\hline line $(50 \mu \mathrm{g})$ & 99 & 100 & 100 & 100 & 93 & 100 & 80 & 53 & 100 & 100 & 100 & 100 & \\
\hline Neo & 100 & 100 & 54 & 75 & 0 & 0 & 7 & 100 & 100 & 100 & 100 & 100 & \\
\hline Oxy & 99 & 100 & 100 & 50 & 86 & 100 & 80 & 53 & 100 & 100 & 100 & 100 & \\
\hline Stre & 100 & 100 & 92 & 75 & 0 & 0 & 7 & 0 & 100 & 100 & 100 & 100 & \\
\hline $\begin{array}{l}\text { Sulph } \\
\text { trim }\end{array}$ & 76 & 60 & 8 & 0 & 29 & 0 & 0 & 27 & 50 & 50 & 0 & 0 & \\
\hline Tetr & 77 & 100 & 100 & Ju & 80 & & & & 10 & 10 & 10 & 100 & \\
\hline & 100 & 100 & 100 & 75 & 100 & 10 & 80 & 100 & 100 & 100 & 100 & 100 & \\
\hline Chloramphenicol $(50 \mu \mathrm{g})$ & 100 & 100 & 100 & 100 & 100 & 100 & 87 & 100 & 100 & 100 & 100 & 100 & \\
\hline
\end{tabular}

* Includes unclustered strains associated with phenons 1-5 (Fig. 1).

$\dagger$ Values in parentheses are the antibiotic concentrations on the Multodiscs.

all are characteristic of the species $L$. innocua (Seeliger, 1981 ; Rocourt \& Catimel, 1985). Where the serovar is known (Table 1), the majority belonged to serovar $6 \mathrm{a}$ (formerly $4 \mathrm{f}$, antigen $\mathrm{XV}$ ), serovar 6b (formerly 4g, antigen XI) (see Seeliger, 1981) or serovar 4ab, serovars found most commonly in strains of $L$. innocua (Seeliger \& Jones, 1986).

Phenon 4 contained eight strains that were characteristic of the species L. ivanovii. All were markedly haemolytic and none produced acid from mannitol or rhamnose. All were received as serovar 5 (Table 1). All the phenon 5 strains were rough (as determined by colony surface) but could not otherwise be unequivocally distinguished from strains in phenons 1, 2 and 3. Two strains (C260 and NCTC 5343) were attached to phenons 1 to 5. Neither strain was haemolytic, both produced acid from xylose and NCTC 5343 also produced acid from rhamnose. With the exception of the marked haemolysis of strains in phenon 4 and the serotyping of all phenon 4 strains as serovar 5 , there was thus no one character that distinguished between these five phenons, the characters of phenons 1 to 5 are therefore given as one set in Table 2.

Phenon 6 contained the type strains of $L$. grayi and L. murrayi. Within the phenon there was internal structure that corresponded to two closely related taxa, but one strain received as $L$. grayi (C360) clustered more closely with $L$. murrayi.

Phenon 7 was equivalent to group 3 of Thornley \& Sharpe (1959). All the strains were Grampositive, motile, catalase-negative rods.

Phenon 8 represented Lact.plantarum. The apparent closer relationship of these strains to the atypical lactobacilli (phenons 7, 9, 10 and 11) than to other members of the genus Lactobacillus (phenon 20) was due mainly to quantitative similarities between the characters of the strains in phenon 8 and phenons $7,9,10$ and 11 . When the simple matching coefficient, which eliminates quantitative differences, was used, the clustering of phenons $7,9,10$ and 11 remained unchanged but Lact. plantarum, while remaining a distinct cluster, showed the closest similarity (phenogram not shown) to the other lactobacilli. This was the only grouping affected by the use of different methods of computation, but it serves to emphasize the importance of using more than one similarity coefficient in numerical taxonomic studies.

Strains previously considered sufficiently similar to be placed in one group (group 2; Thornley $\&$ Sharpe, 1959) were recovered in phenons 9, 10 and 11. All were Gram-positive, non-motile, catalase-negative rods. The distinguishing features of the three phenons are listed in Table 2. 
Phenon 12 (overall similarity $85 \%$ ) contained 10 strains designated as group 1 (Thornley \& Sharpe, 1959) and five strains of $B$. thermosphacta including the type strain ATCC 11509. Within the cluster there was some evidence of internal structure (not shown in Fig. 1) but inspection of the test results did not reveal any distinguishing characters. The internal structure probably represented strain variation within the species $B$. thermosphacta.

Phenon 13 contained the two cultures of the only known (and type) strain of Listeria denitrificans recently reclassified as Jonesia denitrificans (Rocourt et al., 1987a). The closest similarity was to phenon 14 (Cellulomonas). Strains in both these phenons digested cellulose.

Phenon 15 represented the species Kurthia zopfii.

Phenon 16 contained three strains, two of which were received as E. rhusiopathiae. However, all were catalase-positive and easily distinguished from the type strain of E. rhusiopathiae (Table 2).

Phenon 17 contained one strain of 'Corynebacterium betae' and one of 'Cor. poinsettiae'. These have now been reclassified as Curtobacterium flaccumfaciens subsp. betae and Curtobacterium flaccumfaciens subsp. poinsettiae respectively (Collins \& Jones, 1983). The strains were included in the study because Seeliger (1961) noted that 'Cor. poinsettiae' could be confused with $L$. monocytogenes. Attached to this phenon at $78 \% S$ was another plant pathogenic bacterium, 'Corynebacterium rathayi', now reclassified in the genus Clavibacter (Davis et al., 1984).

Phenon 18 contained three strains, including the type strain of $E$. rhusiopathiae. It exhibited a similarity of about $75 \%$ to phenon 19 and to one unclustered strain and identified as Erysipelothrix. All these strains were catalase-negative.

Phenon 20 contained five strains of various species of the genus Lactobacillus (Table 1).

After the completion of the computer analysis all the strains in phenons $7,8,9,10,11,12,19$ and 20, and unclustered strains received as Erysipelothrix spp., atypical lactobacilli or Grampositive rods, were tested for growth on MRS medium (De Man et al., 1960), devised for growth of lactobacilli, and STAA agar (Gardner, 1966), a selective medium for B. thermosphacta. Good growth on MRS medium was exhibited only by strains of phenons 8 (Lact. plantarum) and 20 (Lactobacillus spp.), two strains of phenon 19 (C484 and C485) and two unclustered strains (C461 and C471). Only the strains of phenon 12 (B. thermosphacta) grew on STAA agar.

\section{Chemical studies}

The $\mathrm{mol} \% \mathrm{G}+\mathrm{C}$ contents of the DNA of representative strains are listed in Table 1 .

Strains of Brochothrix and Listeria (but not L. denitrificans), Lact. plantarum, Lact. mali, Lact. yamanashiensis and those of phenons 7, 9,10,11 and 19 all contained meso-diaminopimelic acid as the dibasic amino acid. Alanine and glutamic acid were also present. The cell walls of $L$. denitrificans contained lysine, alanine, glutamic acid and glycine. Lysine and alanine were present in all three strains of $E$. rhusiopathiae examined but the presence of glutamic acid, glycine and serine varied between the strains. In contrast, strains $C 335$ and $C 338$ received as ' $E$. rhusiopathiae' phenon 16, contained meso-diaminopimelic acid and alanine. These two strains also contained mycolic acids.

The major long chain fatty acid of $B$. thermosphacta was 12-methyl tetradecanoic acid (anteiso$\mathrm{C}_{15: 0}$ ) with substantial amounts of 14-methylhexadecanoic (anteiso- $\mathrm{C}_{17: 0}$ ) and 13-methyltetradecanoic (iso- $\mathrm{C}_{15: 0}$ ) acids. The major fatty acid of $L$. denitrificans was also 12-methyltetradecanoic acid (anteiso- $\mathrm{C}_{15: 0}$ ) but with substantial amounts of hexadecanoic $\left(\mathrm{C}_{16: 0}\right)$, 14methylpentadecanoic (iso- $\mathrm{C}_{16: 0}$ ) and 14-methylhexadecanoic (anteiso- $\mathrm{C}_{17: 0}$ ) acids. The major fatty acid composition of the genus Listeria (phenons 1 to 6, Fig. 1) was 14-methylhexadecanoic (anteiso- $\mathrm{C}_{17: 0}$ ) with substantial amounts of other methyl branched acids (Table 3).

No respiratory quinones were detected in representative strains of Lact. plantarum, the atypical lactobacilli of phenons 7, 9, 10 and 11, nor in E. rhusiopathiae. The remaining strains examined contained menaquinones as the sole respiratory quinones. All Listeria (except $L$. denitrificans) and Brochothrix strains examined contained MK-7 as the major menaquinone component with MK-6 and MK-5 as minor components. The major menaquinone in $L$. denitrificans was MK-9 with MK-7 and MK-8 as minor components. Strains of Lact. mali and Lact. yamanashiensis contained MK -8 and MK -9 as major components with MK-10 and MK-7 


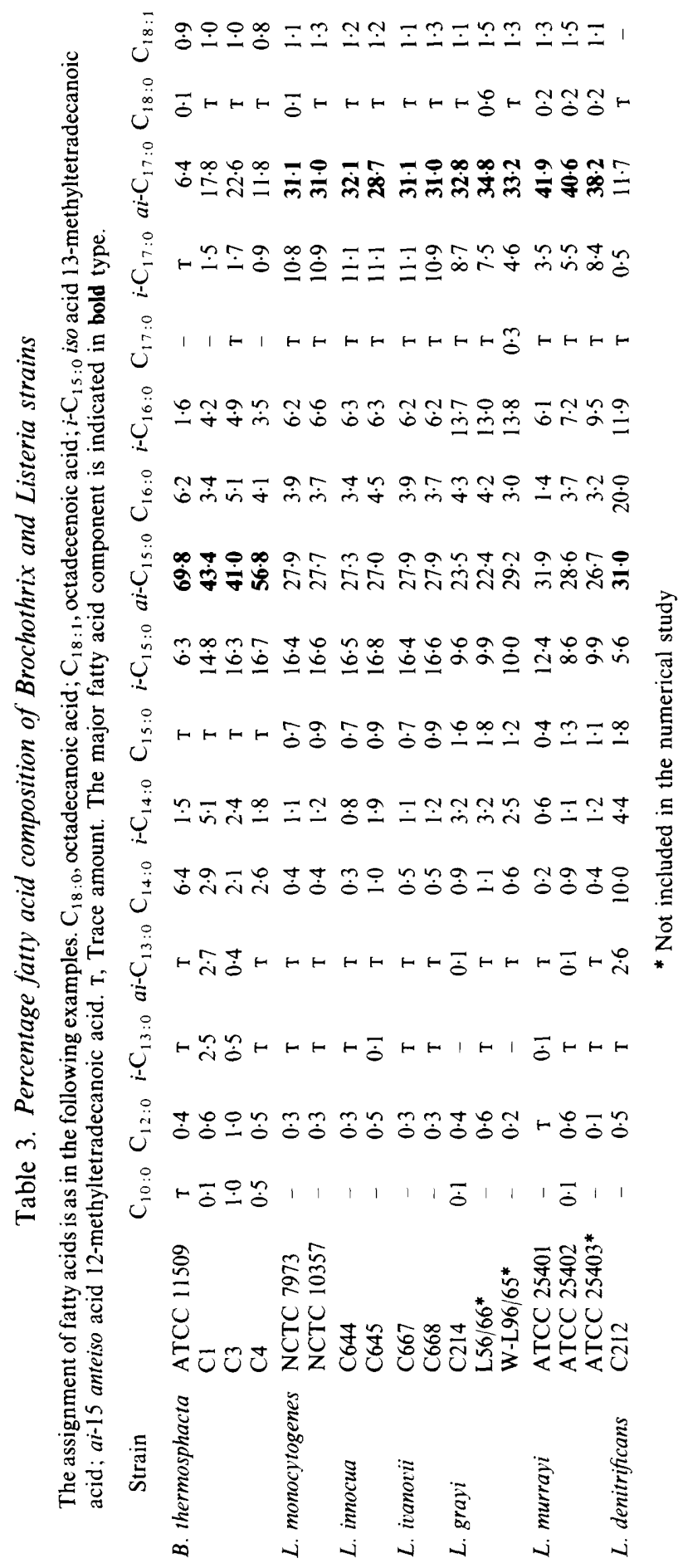


as minor components. The major menaquinone components of the atypical Erysipelothrix strains were $\mathrm{MK}-8\left(\mathrm{H}_{2}\right)$ and $\mathrm{MK}-9\left(\mathrm{H}_{2}\right)$ with small amounts of $\mathrm{MK}-7\left(\mathrm{H}_{2}\right), \mathrm{MK}-8$ and MK-9. Cytochrome composition was determined only for $L$. monocytogenes NCTC 7973, L. innocua Seeliger L3479, L. ivanovii C667 and C668, L. grayi Seeliger L332/64 and L. murrayi ATCC 25401. All contained cytochromes $a_{1} b d o$.

\section{DISCUSSION}

The main aim of this study was to clarify the taxonomy of the listeriae, bacteria designated atypical lactobacilli, and bacteria of the genera Brochothrix and Erysipelothrix.

Cellulomonas strains were included in the study because bacteria previously known as $L$. denitrificans hydrolyse cellulose and earlier studies had failed to classify them in any known taxon (see Collins et al., 1983). As expected L. denitrificans was quite distinct from phenons representing the genus Listeria, but while it exhibited the closest relationship to the genus Cellulomonas, it cannot be considered a member of that genus. Since this work was completed, Listeria denitrificans has been reclassified in a new genus as Jonesia denitrificans on the basis of the results of $16 \mathrm{~S}$ rRNA oligonucleotide cataloguing studies (Rocourt et al., 1987a).

The results obtained with the three plant pathogenic corynebacteria are in agreement with the recent changes in the classification of these bacteria. The strains of 'Cor. poinsettiae' and 'Cor. betae', now transferred to the genus Curtobacterium (Collins \& Jones, 1983) clustered together and showed the closest phenetic similarity to 'Cor. rathayi', now reclassified in the genus Clavibacter (Davis et al., 1984).

The clustering of the strains designated atypical lactobacilli was in broad, but not complete, agreement with the grouping of these strains by Thornley \& Sharpe (1959) on the basis of fewer properties. The clustering of all the strains of Thornley and Sharpe group 1 with representatives of $B$. thermosphacta (Fig. 1) together with their cell wall and menaquinone composition and the $\mathrm{mol} \% \mathrm{G}+\mathrm{C}$ content of the DNA, indicates that these strains should be designated $B$. thermosphacta. This is in accord with the results of Jones (1975) based on only one strain of Thornley and Sharpe group 1.

In keeping with the results of Thornley and Sharpe (1959), all their group 3 strains formed a distinct cluster (phenon 7). These strains were quite distinct from B. thermosphacta. As noted by Thornley \& Sharpe (1959) the cell wall peptidoglycan contained meso-diaminopimelic acid. However, the strains were catalase-negative and did not contain menaquinones. The apparent similarity of these bacteria to Lact. plantarum has been discussed previously; phenon 7 strains were distinct from the lactobacilli and more similar to strains designated group 2 by Thornley $\&$ Sharpe (1959).

In contrast to the findings of Thornley \& Sharpe (1959), strains allocated by these authors to group 2 formed three clusters (phenons 9, 10 and 11). Comparison of the properties of these strains with those isolated from meat and studied by Shaw \& Harding (1985) suggests that strains of phenon 9 resemble strains designated Lact. carnis by these authors and strains of phenon 11 bear some resemblance to Lact. divergens (Hölzapfel \& Gerber, 1983). Neither of these species was included in the study but our results indicate that phenons 9,10 and 11 are not members of the genus Lactobacillus. Moreover, none of the strains grew on MRS medium (De Man et al., 1960). Further work is in progress to resolve the taxonomic position of the strains in phenons $7,9,10$ and 11 .

Of the five strains of E. rhusiopathiae studied, two isolates from human sources exhibited properties typical of the species and clustered with the type strain (NCTC 8163) in phenon 18. The other two strains (phenon 16) were received as E. rhusiopathiae and one (C335-MEW22) was designated $E$. rhusiopathiae serogroup IV by Gledhill (1945), probably the only strain to be allocated to this serogroup (P. H. A. Sneath, personal communication). The reason for this misidentification is probably because the strains grow very poorly on the usual laboratory media and consequently give a negative catalase reaction. On $\mathrm{BM}$ agar, incubated at $30^{\circ} \mathrm{C}$, a positive, but weak catalase reaction was obtained. When $1 \%(\mathrm{v} / \mathrm{v})$ Tween 80 was incorporated in BM agar very good growth was obtained. Cell wall and menaquinone composition and $\mathrm{G}+\mathrm{C}$ 
content of the DNA indicate that these strains are probably lipophilic corynebacteria similar to Cor. bovis (Collins \& Cummins, 1986). Very recently a new species of Erysipelothrix has been named, E. tonsillarum (Takahashi et al., 1987). These bacteria were distinguished from $E$. rhusiopathiae solely on the basis of DNA-DNA hybridization studies.

With the exception of $L$. denitrificans ( $J$. denitrificans), the strains received or isolated as members of the genus Listeria clustered into six phenons. The high similarity of all these strains $(80 \%)$ and their identical cell wall, menaquinone, fatty acid and cytochrome compositions indicate that all, including L. grayi and L. murrayi (phenon 6), are members of the genus Listeria.

The clustering of the type strains of $L$. grayi and $L$. murray i in one cluster indicates that these strains are members of one species. These results do not support the suggestion of Stuart \& Welshimer $(1973,1974)$, based on DNA-DNA hybridization studies, that $L$. grayi and $L$. murrayi should be reclassified in a new genus 'Murraya'. They do, however, support the suggestion made by these authors that $L$. murrayi should be considered as a subspecies of $L$. grayi. The retention of $L$. grayi subsp. grayi and L. grayi subsp. murrayi in the genus Listeria is in agreement with the results of previous numerical taxonomic (Wilkinson \& Jones, 1977) and cell wall (Fiedler \& Seger, 1973; Fiedler et al., 1984) studies and the recent 16S rRNA cataloguing results of Rocourt et al. $(1987$ b).

The recovery of strains received as L. monocytogenes, L. innocua and Listeria spp. (Table 1) in five very closely related phenons and some unclustered strains, is only in partial agreement with the results of the DNA-DNA hybridization studies of Rocourt et al. (1982). These authors detected five genomic species among strains previously classified as $L$. monocytogenes sensu lato (Rocourt et al., 1982), L. monocytogenes sensu stricto, and species subsequently validly published as L. innocua (Seeliger, 1981, 1983), L. welshimeri (Rocourt \& Grimont, 1983). L. seeligeri (Rocourt \& Grimont, 1983) and L. ivanovii (Seeliger et al., 1984). These genomic species were distinguished by a few phenotypic tests (Rocourt et al., 1983b), and a further more extensive study (Rocourt \& Catimel, 1985) failed to detect any further distinguishing properties. Reference strains of $L$. welshimeri and $L$. seeligeri were not included in the present study nor was the CAMP test with Staphylococcus aureus and Rhodococcus equi done initially. Examination of the strains in phenons 1-5 by the CAMP test (Rocourt et al., 1983b) showed that all strains in phenons 1 and 2 were CAMP positive with Staph. aureus and all strains in phenon 4 were CAMP positive with Rhod. equi. None of the phenons could be equated with either $L$. welshimeri or $L$. seeligeri. Phenons 1 and 2 exhibited properties typical of $L$. monocytogenes. Phenon 3 contained the type strain of $L$. innocua and all were non-haemolytic. Phenon 4 exhibited the properties of $L$. ivanovii. Phenon 5 contained two rough, non-haemolytic strains received as $L$. monocytogenes and these could not be distinguished from the other strains in this phenon which were also nonhaemolytic and rough. The five ungrouped strains that fell between phenons 3 and 4 were nonhaemolytic even by the modifications of the CAMP test (Rocourt et al., 1983b). In the absence of the genomic data for the type strains (Rocourt et al., 1982) that were included in the study, there would be a strong argument for grouping all the strains in the phenons $1-5$ and the related ungrouped strains into one phenon of species rank, and regarding the apparent clusters as subspecies. Such an interpretation is in agreement with electrophoretic protein patterns of strains of all the named species in the genus Listeria (Lamont et al., 1986). These authors detected no significant interspecies variation between $L$. monocytogenes, $L$. innocua, $L$. welshimeri, L. seeligeri and L. ivanovii. There is virtually no correlation between species and serovar (Table 1) with the exception of L. ivanovii strains (phenon 4), all of which are members of serovar 5 . The close phenotypic similarity between the five genomic species of Listeria has also been noted by McLauchlin (1987).

Listeria has always been recognized as an animal pathogen and in the last ten years, increasingly as a human pathogen (see McLauchlin, 1987). A comparative study (Rocourt et al., $1983 a$ ) of the virulence to mice of the five genomic species of $L$. monocytogenes sensu lato (Rocourt et al., 1982) showed that, under the conditions of test used, only L monocytogenes and $L$. ivanovii were significantly pathogenic. $L$. seeligeri has also been isolated from a human infection (Rocourt et al., 1986) and L. innocua has been recovered from human material (Rocourt \& Seeliger, 1985). L. welshimeri has, to date, not been isolated from human sources (Rocourt \& 
Seeliger, 1985). Although the three species considered to be the most likely to cause listeriosis, $L$. monocytogenes, $L$. seeligeri and $L$. ivanovii, are all haemolytic under appropriate test conditions, the basis of virulence in Listeria species is still not understood. Because the five genomic species of $L$. monocytogenes sensu lato have such similar phenotypes, the presence of one species in a particular environment should be taken as indicative of the presence of the others. It is therefore important to distinguish these forms from the subspecies of $L$. grayi and from other similar bacteria such as $B$. thermosphacta and the atypical lactobacilli of phenons 7, 9, 10 and 11 which are also commonly found in raw and processed meat. The distinguishing characters of $L$. monocytogenes sensu lato, L. grayi, B. thermosphacta and the atypical lactobacilli are given in Table 2.

In conclusion the results of the study indicate the following. (1) The genomic species $L$. monocytogenes, $L$. innocua and $L$. ivanovii are phenotypically very similar but quite distinct from L. grayi. (2) L. grayi and L. murrayi represent only one species and on grounds of priority the species should be named L. grayi. (3) The results obtained with $L$. denitrificans are in agreement with the transfer of this bacterium to a new genus Jonesia (Rocourt et al., 1987a). (4) Some strains designated group 1 by Thornley \& Sharpe (1959) are members of the species $B$. thermosphacta. (5) Strains of groups 2 and 3 of Thornley \& Sharpe (1959) represent four taxa not related to the genera Brochothrix, Erysipelothrix and Listeria. Phenotypically, they most closely resemble the genus Lactobacillus but further work is required to show whether they are members of this genus or an as yet undescribed taxon. (6) Some strains of lipophilic corynebacteria may be misidentified as Erysipelothrix if cultured on unsuitable media.

Work on the plant pathogens NCPPB 363, 797 and 844 was done under MAFF licence number PHF 157/22 issued under the Plant Pests (Great Britain) Order 1980. One of us (S. B. F) thanks the British Council for support.

\section{REFERENCES}

CARR, J. G. \& Davies, P. A. (1970). Homofermentative lactobacilli of ciders including Lactobacillus mali nov. spec. Journal of Applied Bacteriology 33, 768774.

Collins, C. H. \& LYNE, P. M. (1970). Microbiological Methods, 3rd edn. London: Butterworth.

Collins, M. D. \& Cummins, C. S. (1986). The genus Corynebacterium. In Bergey's Manual of Systematic Bacteriology, vol. 2, pp. 1266-1276. Edited by P. H. A. Sneath, N. S. Mair \& M. E. Sharpe. Baltimore: Williams \& Wilkins.

Collins, M. D. \& Jones, D. (1980). Lipids in the classification and identification of coryneform bacteria containing peptidoglycans based on 2,4-diaminobutyric acid. Journal of Applied Bacteriology 48, 459-470.

Collins, M. D. \& Jones, D. (1983). Reclassification of Corynebacterium flaccumfaciens, Corynebacterium betae, Corynebacterium oortii and Corynebacterium poinsettiae in the genus Curtobacterium as Curtobacterium flaccumfaciens comb. nov. Journal of General Microbiology 129, 3545-3548.

Collins, M. D., Pirouz, T., Goodfellow, M. \& MinNikin, D. E. (1977). Distribution of menaquinones in actinomycetes and corynebacteria. Journal of General Microbiology 100, 221-230.

Collins, M. D., Shah, H. N. \& Minnikin, D. E. (1980). A note on the separation of natural mixtures of bacterial menaquinones using reverse phase thinlayer chromatography. Journal of Applied Bacteriology 48, 277-282.

Collins, M. D. Feresu, S. \& Jones, D. (1983). Cell wall, DNA base composition and lipid studies on Listeria denitrificans (Prevot). FEMS Microbiology Letters 18, 131-134.
Cowan, S. T. (1974). Cowan and Steel's Manual for the Identification of Medical Bacteria, 2nd edn. Cambridge: Cambridge University Press.

Davis, G. H. G. (1955). The classification of lactobacilli from the human mouth. Journal of General Microbiology 13, 481-493.

Davis, M. J., Gillespie, A. G., JR, Vidaver, A. K. \& HARRIS, R. W. (1984). Clavibacter, a new genus containing some phytopathogenic coryneform bacteria including Clavibacter xyli subsp. $x y l i$ and Clavibacter xyli subsp. cynodontis subsp. nov., pathogens that cause ratoon stunting disease of sugar-cane and Bermudagrass stunting disease. International Journal of Systematic Bacteriology 34, 107-117.

De Man, J. C., Rogosa, M. \& Sharpe, M. E. (1960). A medium for the cultivation of lactobacilli. Journal of Applied Bacteriology 23, 130-135.

Fiedler, F. \& SEgER, J. (1983). The murein types of Listeria grayi, Listeria murrayi and Listeria denitrifcans. Systematic and Applied Microbiology 4, 444450.

FIEDler, F., Seger, J., SChrettenbrünNer, A. \& SEEliger, H. P. R. (1984). The biochemistry of murein and cell wall teichoic acids in the genus Listeria. Systematic and Applied Microbiology 5, 360-376.

GARDNER, G. A. (1966). A selective medium for the enumeration of Microbacterium thermosphactum in meat and meat products. Journal of Applied Bacteriology 29, 455-460.

Garvie, E. I. (1976). Hybridization between the deoxyribonucleic acids of some strains of heterofermentative lactic acid bacteria. International Journal of Systematic Bacteriology 26, 116-122. 
GARVIE, E. I. (1978). Streptococcus raffinolactis (OrlaJensen and Hansen): a group $\mathrm{N}$ streptococcus found in raw milk. International Journal of Systematic Bacteriology 28, 190-193.

GLedhill, A. W. (1945). The antigenic structure of Erysipelothrix. Journal of Pathology and Bacteriology 57, 179-189.

GOWER, J. C. (1971). A general coefficient of similarity and some of its properties. Biometrics 27, 851-871.

HölzaPfEL, W. H. \& Gerber, E. S. (1983). Lactobacillus divergens $\mathrm{sp}$. nov., a new heterofermentative Lactobacillus species producing L(+)-lactate. Systematic and Applied Microbiology 4, 522-534.

Hugh, R. \& Leifson, E. (1953). The taxonomic significance of fermentative versus oxidative metabolism of carbohydrates by various Gram-negative bacteria. Journal of Bacteriology 66, 24-26.

Jones, C. W. \& RedfeARN, E. R. (1966). Electron transport in Azotobacter vinelandii. Biochimica et biophysica acta 113, 467-481.

Jones, C. W. \& Redfearn, E. R. (1967). The cytochrome system of Azotobacter vinelandii. Biochimica et biophysica acta 143, 340-353.

JONES, D. (1975). A numerical taxonomic study of coryneform and related bacteria. Journal of General Microbiology 87, 52-96.

JONES, D. (1986). The genus Erysipelothrix. In Bergey's Manual of Systematic Bacteriology, vol. 2, pp. 12451249. Edited by P. H. A. Sneath, N. S. Mair \& M. E. Sharpe. Baltimore: Williams \& Wilkins.

Kovacs, N. (1956). Identification of Pseudomonas pyocyanea by the oxidase reaction. Nature, London $178,703$.

Lamont, R. J., Petrie, D. T., Melvin, W. T. \& Postlethwaite, R. (1986). An investigation of the taxonomy of Listeria species by comparison of elecrophoretic protein patterns. In Listeriose, Listeria, Listeriosis 1985-1986. Proceedings of the 9th International Symposium on the Problems of Listeriosis, pp. 41-46. Edited by A.-L. Cortieu, E. P. Espaze \& A. E. Reynaud. Nantes: University of Nantes Press

McLauchlin, J. (1987). A review: Listeria monocytogenes, recent advances in the taxonomy and epidemiology of listeriosis in humans. Journal of Applied Bacteriology 63, 1-11.

Minnikin, D. E., Alshamaony, L. \& Goodfellow, M. (1975). Differentiation of Mycobacterium, Nocardia, and related taxa by thin layer chromatographic analysis of whole-organism methanolysates. Journal of General Microbiology 88, 200-204.

Rocourt, J. \& Catimel, B. (1985). Caracterisation biochimique des éspeces du genre Listeria. Zentralblatt für Bakteriologie, Mikrobiologie und Hygiene (Abtielung I, Originale A) 260, 221-231.

Rocourt, J. \& Grimont, P. A. D. (1983). Listeria welshimeri $\mathrm{sp}$. nov. and Listeria seeligeri $\mathrm{sp}$. nov. International Journal of Systematic Bacteriology 33, 866-869.

Rocourt, J. \& SeEliger, H. P. R. (1985). Distribution des éspeces du genre Listeria. Zentralblatt für Bakteriologie, Mikrobiologie und Hygiene (Abteilung I, Originale A) 259, 317-330.

Rocourt, J., Grimont, F., Grimont, P. A. D. \& SEeliger, H. P. R. (1982). DNA relatedness among serovars of Listeria monocytogenes sensu lato. Current Microbiology 7, 383-388.
Rocourt, J. Alonso, J.-M. \& Seeliger, H. P. R $(1983 a)$. Virulence comparée des cinq groupes génomiques de Listeria monocytogenes (sensu lato). Annales de microbiologie 134A, 359-364.

Rocourt, J., SchrettenbrünNer, A. \& SeEliger, H. P. R. (1983b). Differenciation biochimique des groupes génomiques de Listeria monocytogenes (sensu lato). Annales de microbiologie 134A, 65-71.

Rocourt, J., HoF, H., SCHRETTENBRÜNNER, A., Malinverni, R. \& Bille, J. (1986). Meningite purulente aigue à Listeria seeligeri chez un adult immunocompétent. Schweizerische medizinische Wochenschrift 116, 248-251.

Rocourt, J., Wehmeyer, U. \& Stackebrandt, E. (1987a). Transfer of Listeria denitrificans to a new genus Jonesia gen. nov. as Jonesia denitrificans comb. nov. International Journal of Systematic Bacteriology 37, 266-270.

Rocourt, J., Wehmeyer, U., Cossart, P. \& StackeBRANDT, E. $(1987 b)$. Proposal to retain Listeria murrayi and Listeria grayi in the genus Listeria. International Journal of Systematic Bacteriology 37, 298-300.

SCHLeifer, K. H. \& Kandler, O. (1972). Peptidoglycan types of bacterial cell walls and their taxonomic implications. Bacteriological Reviews 36, 407477.

SEeliger, H. P. R. (1961). Listeriosis, 2nd edn. New York: S. Karger.

Seeliger, H. P. R. (1981). Apathogene listerien; $L$. innocua sp. n. Zentralblatt für Bakteriologie, Mikrobiologie und Hygiene (Abtielung I, Originale A) 249, 487-493.

SeEliger, H. P. R. (1983). Validation of the publication of new names and new combinations previously effectively published outside the IJSB. List no. 10. International Journal of Systematic Bacteriology 33, 438-440.

Seeliger, H. P. R. \& Jones, D. (1986). The genus Listeria. In Bergey's Manual of Systematic Bacteriology, vol. 2, pp.1235-1245. Edited by P. H. A. Sneath, N. S. Mair \& M. E. Sharpe. Baltimore: Williams \& Wilkins.

SEeliger, H. P. R., RoCourt, J. SCHRETTENBRÜNNER, A., Grimont, P. A. D. \& Jones, D. (1984). Description of Listeria ivanovii sp. nov. International Journal of Systematic Bacteriology 34, 336-337.

SHAW, B. G. \& HaRding, C. M. (1984). A numerical taxonomic study of lactic acid bacteria from vacuum-packed beef, pork, lamb and bacon. Journal of Applied Bacteriology 56, 25-40.

Shaw, B. G. \& HaRding, C. M. (1985). Atypical lactobacilli from vacuum-packaged meats : comparison by DNA hybridization, cell composition and biochemical tests with a description of Lactobacillus carnis sp. nov. Systematic and Applied Microbiology 6, 291-297.

SNEATH, P. H. A. (1979). BASIC program for a significance test for two clusters in euclidean space as measured by their overlap. Computers and Geosciences 5, 143-155.

SNEath, P. H. A. \& Johnson, R. (1972). The influence on numerical taxonomic similarities of errors in microbiological tests. Journal of General Microbiology 72, 377-392.

SNEATH, P. H. A. \& JonEs, D. (1986). The genus Brochothrix. In Bergey's Manual of Systematic Bacte- 
riology, vol. 2, pp.1249-1253. Edited by P. H. A Sneath, N. S. Mair \& M. E. Sharpe. Baltimore: Williams \& Wilkins.

SNeath, P. H. A. \& Sokal, R. R. (1973). Numerical Taxonomy. The Principles and Practice of Numerical Classification. San Francisco: W. H. Freeman.

Stevens, M. (1969). Development and use of multiinoculation test methods for a taxonomic study. Journal of Medical Laboratory Technology 26, 253263.

Stuart, S. E. \& Welshimer, H. J. (1973). The intrageneric relatedness of Listeria Pirie. International Journal of Systematic Bacteriology 23, 8-14.

StUART, S. E. \& Welshimer, H. J. (1974). Taxonomic re-examination of Listeria Pirie and transfer of Listeria grayi and Listeria murrayi to a new genus Murraya. International Journal of Systematic Bacteriology 24, 177-185.

Takahashi, T., Fujisawa, T., Benno, Y., Tamura, Y., Sawada, T., Suzuki, S., Muramatsu, M. \&
MitsuoKa, T. (1987). Erysipelothrix tonsillarum sp. nov. isolated from tonsils of apparently healthy pigs. International Journal of Systematic Bacteriology 37, 166-168.

THORNLEY, M. J. (1957). Observations on the microflora of minced chicken meat irradiated with $4 \mathrm{MeV}$ cathode rays. Journal of Applied Bacteriology 20, 286298.

THORNLEY, M. J. (1960). The differentiation of Pseudomonas from other Gram-negative bacteria on the basis of arginine metabolism. Journal of Applied Bacteriology 23, 37-52.

THORNLEY, M. J. \& ShARPE, M. E. (1959). Microorganisms from chicken meat related to both lactobacilli and aerobic sporeformers. Journal of Applied Bacteriology 22, 368-376.

Wilkinson, B. J. \& Jones, D. (1977). A numerical taxonomic survey of Listeria and related bacteria. Journal of General Microbiology 98, 399-421. 